\title{
The Effects of Investor Sentiment and Limits-to-Arbitrage on the Idiosyncratic Volatility Puzzle*
}

\author{
Hoyoung Ryu, Lecturer, Pusan National University \\ Taehyuk Kim, Emeritus Professor, Pusan National University \\ Daesung Jung $^{* *}$, Adjunct Professor, Pusan National University
}

\begin{abstract}
$\langle$ Abstract $\rangle$
This study examined the effects of investor sentiment and limits-to-arbitrage on the idiosyncratic volatility (IVOL) puzzle in the Korean stock market. The IVOL portfolio analysis revealed that IVOL is negatively associated with stock returns. It indicates the existence of the IVOL puzzle in the Korean stock market. Additionally, the IVOL puzzle observed in the Korean stock market is time-varying. Therefore, this study analyzed whether the IVOL return premium becomes stronger due to investor sentiment and limits-to-arbitrage. According to the results, all the investor sentiment portfolios had a negative IVOL return premium regardless of whether investor sentiment was high or low, and no patterns of the IVOL puzzle due to investor sentiment were found. On the other hand, the IVOL puzzle is observed when limits-to-arbitrage were high as compared to when they were low. Furthermore, the higher the limits-to-arbitrage, the higher the negative IVOL return premium. These results suggest that the IVOL puzzle is caused by stocks with high limits-to-arbitrage and is intensified when limits-to-arbitrage are high.
\end{abstract}

Keywords: Idiosyncratic Volatility Puzzle; Investor Sentiment; Limits-to-Arbitrage; Time-Varying Idiosyncratic Volatility; Korean Stock Market

JEL Classification: G11, G12, G40

* This paper is based on Hoyoung Ryu's doctoral dissertation.

** Corresponding Author. Address: Department of Business Administration, College of Business, Pusan National University, 2, Busandaehak-ro 63beon-gil, Geumjeong-gu, Busan, Korea 46241; E-mail: jungdaesung@pusan.ac.kr; Tel: +82-51-510-2562; Fax: +82-51-581-3144.

Received: September 24, 2019; Revised: November 24, 2020; Accepted: December 11, 2020 


\title{
투자자 심리와 차익거래 제약이 고유변동성 이상현상에 미치는 영향*
}

\author{
류 호 영 (부산대학교 강사) \\ 김 태 혁 (부산대학교 명예교수) \\ 정 대 성 (부산대학교 겸임교수)**
}

\begin{abstract}
본 연구는 한국 주식시장에서 투자자 심리와 차익거래 제약이 고유변동성 이상현상에 미치는 영향에 대해 검증하였다. 먼저, 고유변동성을 기준으로 10 분위 포트폴리오를 구성하여 분석한 결과, 한국 주식시장에 고유변동성 이상현상이 존재하는 것으로 나타났다. 또한, 한국 주식시장에서 관찰되는 고유변동성 이상현상은 시간에 따라 변화하는 경향을 보이며, 이러한 결과가 투자자 심리와 차익거래 제약에 의한 영향인지 밝혀내기 위해 투자자 심리-고유변동성 포트폴리오와 차익거래 제약-고유변동성 포트폴리오를 구성하여 검증을 시행하였다. 분석 결과, 모든 투자자 심리 포트폴리오에서 고유변동성의 음(-)의 프리미엄이 관찰되지만, 투자자 심리의 변동에 따른 고유변동성 이상현상의 유의미한 변화는 확인되지 않았다. 반면, 차익거래 제약의 경우, 차익거래 제약이 낮은 포트폴리오에서는 고유변동성 이상현상이 관찰되지 않지만, 차익거래 제약이 높은 포트폴리오에서는 고유변동성의 음(-)의 프리미엄이 존재하는 것으로 나타났을 뿐만 아니라, 차익거래 제약이 높아질수록 고유변동성의 음(-)의 프리미엄이 강해지는 경향을 가지는 것으로 밝혀졌다. 이러한 결과를 종합하여 볼 때, 한국 주식시장에 존재하는 고유변동성 이상현상은 투자자 심리보다는 차익거래 제약에 의하여 발생하며, 차익거래 제약이 강하게 나타나는 기간 동안 고유변동성 이상현상은 심화된다.
\end{abstract}

핵심 단어 : 고유변동성 이상현상, 투자자 심리, 차익거래 제약, 시간 가변적 고유변동성, 한국 주식시장

JEL 분류기호: G11, G12, G40

* 이 논문은 류호영의 박사학위 논문 일부를 발췌하여 작성되었습니다.

** 연락담당 저자. 주소: 부산광역시 금정구 부산대학로63번길 2 부산대학교 경영대학, 46241; E-mail: jungdaesung@pusan.ac.kr; Tel: 051-510-2562; Fax: 051-581-3144. 


\section{1. 서론}

자산의 위험이 높을수록 이에 대한 보상을 요구하므로 자산의 기대수익률은 높아진다. 이해하기 쉽고 직관적인 이 명제는 전통적 재무이론의 근간을 이루고 있는 위험-수익 상충관계(risk-return trade off)이다. 전통적 재무이론은 위험-수익 상충관계를 기반으로 발전해왔으며, 그 출발에는 현대 포트폴리오 이론이 있다. 현대 포트폴리오 이론의 핵심은 수익은 최대화하는 반면, 위험은 최소화하는 포트폴리오 구성에 있다. 자산의 위험은 체계적 위험과 비체계적 위험으로 구성되어 있으며, 자산의 비체계적 위험은 잘 분산된(well-diversified) 포트폴리오를 구성함으로써 제거할 수 있으므로, 자산의 수익률을 결정하는 위험은 오직 체계적 위험이다. 현대 포트폴리오 이론에서 위험이란 변동성을 의미하므로, 자산의 비체계적이고 고유한 위험을 고유변동성(idiosyncratic volatility)이라고 한다. 투자자는 잘 분산된 포트폴리오의 구성을 통해 특정 자산의 고유변동성을 다른 자산의 고유변동성으로 상쇄할 수 있기 때문에 고유변동성은 자산의 수익률에 영향을 주지 못하지만, 만약 잘 분산된 포트폴리오를 보유하지 못한 투자자가 있다면 위험-수익 상충관계에 따라 그 투자자는 제거되지 않고 남아있는 고유변동성에 대한 보상을 요구할 것이다. 다시 말해, 고유변동성이 높을수록 자산의 기대수익률은 높아야 하므로 고유변동성은 자산의 기대수익률과 양 $(+)$ 의 관계를 가진다. 고유변동성과 주식수익률의 관계에 대해 연구한 초기의 연구들은 고유변동성이 높은 주식일수록 기대수익률이 높게 나타나는 양(+)의 관계를 보고하였다 (Merton, 1987; Goyal and Santa-Clara, 2003).

그러나 고유변동성에 대한 초기의 연구 결과와 반대로, Ang et al.(2006)은 고유변동성은 주식수익률과 음(-)의 관계를 가진다는 연구 결과를 발표하였다. 고유변동성이 낮은 주식의 수익률이 고유변동성이 높은 주식의 수익률보다 높게 나타나는 고유변동성 이상현상-(idiosyncratic volatility puzzle)은 위험이 높을수록 수익률이 높아지는 위험-수익 상충관계로 설명되지 않기 때문에, 고유변동성 이상현상을 둘러싼 학계의 논의가 시작되었다. 논의의 한편에서는 고유변동성 추정 방법이나 포트폴리오 구성 방법에 따라 고유변동성과 주식수익률 간의 음(-)의 관계는 달라질 수 있다고 주장한 반면(Bali and Cakici, 2008; Fu, 2009), 다른 한편에서는 주식수익률에 영향을 미친다고 알려진 요인들을 통제한 후에도 고유변동성 이상현상은 여전히 존재하며, 연구방법에 관계없이 고유변동성과 주식수익률 간에는 음(-)의 관계가 발견된다고 주장하였다 (Ang et al., 2009; Fink et al., 2012).

고유변동성 이상현상은 전통적 재무이론으로 설명할 수 없기 때문에 최근의 연구들은 행동 재무론을 통해 고유변동성 이상현상의 원인을 설명하고 있다. 주식시장에 존재하는 이상현상 (market anomaly)에 대해 전통적 재무이론에 입각한 연구들은 시장 이상현상을 위험요인모형 에서 미처 고려하지 못한 새로운 체계적 위험요인에 의한 현상으로 해석하는 반면, 행동재무론은 인지적 편향에 의한 투자자의 비합리적 거래행태와 차익거래의 제약에 의해 시장 이상현상이 발생한다고 설명한다. 행동재무론적 관점에 입각한 연구들은 크게 두 가지 관점에서 고유변동성 이상현상을 설명한다. 하나는 인지적 편향에 의한 투자자 심리로 인하여 고유변동성 이상현상이 발생한다는 관점이고, 다른 하나는 시장에 존재하는 차익거래의 제약에 의해 고유변동성 
The Effects of Investor Sentiment and Limits-to-Arbitrage on the Idiosyncratic Volatility Puzzle

이상현상이 발생한다는 관점이다. 투자자 심리로 인한 비합리적 거래행태가 고유변동성 이상 현상을 야기한다는 관점은 위험추구형 성향을 가지는 비합리적 투자자들이 고위험 주식을 선호함으로써 주가의 과잉반응을 초래한다고 설명한다(Kumar, 2009; Bali et al., 2011). 비합리적 거래행태로 인해 과대평가된 고위험 주식은 단기적으로는 모멘텀 현상을 보이지만 장기적으로는 수익률이 낮아지는 반전 현상이 나타나고 이로 인해 고유변동성 이상현상이 발생하게 된다. 반면, 시장의 차익거래 제약으로 인해 고유변동성 이상현상이 발생한다는 연구들은 차익거래 비대칭과 같은 시장의 미시구조적 요인을 통해 고유변동성 이상현상을 설명한다(Stambaugh et al., 2015; Gu et al., 2018). 투자자의 인지적 편향에 의한 거래행태로 인해 가격오류(mispricing)가 발생하였을 시, 차익거래자는 과소평가된 주식은 매수하고 과대평가된 주식은 매도하는데, 과소평가된 주식의 매수에는 제약이 없지만 과대평가된 주식을 매도하는 것은 공매도 제약에 의해 제한되기 때문에 비대칭적인 차익거래가 일어나며, 이와 같은 차익거래 비대칭으로 인해 고유변동성 이상현상이 발생한다.

고유변동성 이상현상에 대한 국내의 연구는 이러한 학계의 흐름에 따라 이루어지고 있다. 고유변동성에 대한 초기의 국내연구에서는 위험-수익 상충관계에 따라 고유변동성이 높을수록 주식수익률이 높아지는 양(+)의 관계가 보고되었지만(Lee and Seo, 2007), 이후의 연구에서 고유변동성이 낮은 주식의 수익률이 상대적으로 높게 나타나는 고유변동성 이상현상이 한국 주식시장에서도 관찰된다는 연구 결과가 보고되었다(Kim and Byun, 2011; Eom et al., 2014). 최근의 국내연구들은 행동재무론적 관점에서 고유변동성 이상현상을 분석하여(Kho and Kim, 2014; Eom, 2018), 한국 주식시장의 고유변동성 이상현상은 투자자 심리에 의한 비합리적 거래행태에 기인한 주가의 과잉반응과 차익거래 비대칭으로 인해 발생하는 것임을 밝혀냈다. 행동재무론을 통해 고유변동성 이상현상을 설명하는 국내연구들은 개별 주식에 대한 투자자 심리와 개별 주식이 가지고 있는 차익거래 제약 요인에 집중하고 있다. 전자는 인지적 편향을 가지는 투자자들이 특정 주식집단에 대해 보이는 비합리적인 거래행태로 인해 고유변동성 이상현상이 발생한다고 설명하고 있으며, 후자는 차익거래 제약이 강하게 나타나는 특정 주식집단에서 발생한 고유변동성 이상현상이 시장 전체의 고유변동성 이상현상을 야기한다고 설명한다.

행동재무론을 통해 고유변동성 이상현상을 분석하는 다수의 국내연구들에 의해 한국 주식시장 에서 관찰되는 고유변동성 이상현상의 원인이 밝혀지고 있지만, 본 연구는 기존의 연구에서 더 나아가 특정 주식집단에 의해 고유변동성 이상현상이 발생한다는 사실을 규명할 뿐만 아니라, 특정 시점에서 고유변동성 이상현상이 심화되는 현상을 제시한다. 고유변동성 이상현상의 시간에 따른 변화를 분석하기 위해 다음과 같이 연구를 진행한다. 먼저, 분석을 위해 기존의 연구들에서 투자자 심리와 차익거래 제약을 나타내는 것으로 보고된 변수들을 사용하여 각각 하나의 지수를 구성하고, 거시경제변수들이 그 지수에 미치는 영향을 제거한 이후의 새로운 투자자 심리 지수와 차익거래 제약 지수를 구축한다. 다음으로 투자자 심리와 차익거래 제약이 고유변동성 이상현상에 미치는 영향을 분석한다. 고유변동성과 투자자 심리, 차익거래 제약 포트폴리오를 구성하여 포트폴리오 분석을 통해 한국 주식시장에서 고유변동성 이상현상을 
발생시키는 원인이 무엇인지 밝혀내고, 나아가 고유변동성 이상현상을 심화시키는 원인을 실증적으로 분석하고자 한다.

본 연구를 통해 기대되는 의의는 다음과 같다. 첫째, 기존의 연구들에서 보고된 변수들을 종합하여 단일 지수를 구성하여 분석함으로써, 투자자 심리와 차익거래 제약이 한국 주식시장에 미치는 영향에 대해 보다 의미 있는 결과를 제시할 수 있을 것으로 기대된다. 둘째, 한국 주식시장의 특성을 반영하는 변수들을 사용함으로써, 한국 주식시장에 존재하는 고유변동성 이상현상의 특성을 정확히 포착할 수 있을 것으로 기대된다. 셋째, 고유변동성 이상현상을 야기하는 원인을 설명하는 것에서 더 나아가 고유변동성 이상현상을 심화시키는 원인을 밝혀냄으로써 한국 주식시장의 고유변동성 이상현상을 연구하는 데 있어서 새로운 실증 결과를 제시할 수 있을 것으로 기대된다. 본 연구는 이러한 분석을 통해 현재 한국 주식시장에서 투자자를 보호하기 위해 시행되고 있는 제도들이 실제 투자자들에게 미치는 결과를 도출함으로써, 한국 주식시장과 유관기관들이 나아가야할 방향을 제시하는데 이론적 근거를 제공할 수 있을 것으로 기대된다. 본 연구는 다음과 같이 구성된다. 제 1 장 서론에 이어 제 2 장에서는 이론적 배경과 선행연구를 고찰한다. 제 3 장은 실증분석에 사용되는 자료와 방법론에 대해 설명한다. 제 4 장에서 실증분석 결과를 제시하고, 제 5 장에서는 본 연구의 결론과 주요 시사점들을 제시한다.

\section{2. 이론적 배경 및 선행연구}

Ang et al.(2006)이 미국 주식시장을 대상으로 한 실증연구를 통해 고유변동성과 수익률 간에는 음(-)의 관계가 존재한다는 연구 결과를 발표한 이후, 고유변동성에 관한 연구들은 Ang et al.(2006)이 보고한 고유변동성 이상현상을 설명하는 데에 초점이 맞춰졌다. 고유변동성 이상현상은 기존의 위험-수익 상충관계로는 설명되지 않는 퍼즐(puzzle)이었기 때문에, 이를 설명하려는 연구들은 전통적 재무이론이 아닌 행동재무론을 통해 고유변동성 이상현상의 설명을 시도하였다. 행동재무론에 입각한 고유변동성 이상현상에 관한 연구는 크게 두 갈래로 분류할 수 있는데, 하나는 비합리적 투자자들의 인지적 편향에 의한 거래행태에 따른 현상으로 설명하는 것이고, 다른 하나는 시장에 존재하는 차익거래 제약을 통해 고유변동성 이상현상을 설명하는 것이다.

비합리적 투자자들의 거래행태를 통해 고유변동성 이상현상을 설명하려는 연구는 시장에 참여하는 잡음 거래자(noise trader)의 투자자 심리가 고유변동성 이상현상을 유발한다고 설명한다. 잡음 거래자들은 자신의 예측 능력을 과신하며, 이러한 인지적 편향은 잡음 거래자가 과거에 경험한 성과를 지나치게 맹신하는 자기 고양적 편향에 의해 강해진다. 위험회피형 성향을 가지는 정보거래자(informed trader)와 달리 사적 정보를 과신하는 투자자들은 위험추구형 성향을 가지므로, 복권형 주식(lottery stock)과 같은 변동성이 높은 고위험 주식을 선호한다. 이러한 잡음 거래자의 투자행태는 고유변동성이 높은 주식가격의 과잉반응을 초래하여 단기적 으로는 모멘텀 현상을 야기하지만, 장기적으로는 반전 현상으로 인하여 낮은 수익률을 보이게 된다. 이들 잡음 거래자가 선호하는 복권형 주식은 수익률 분포에 있어서 극단적인 양(+)의 왜도를 가지므로, 왜도와 수익률의 음(-)의 관계를 증명함으로써 고유변동성 이상현상을 설명할 
The Effects of Investor Sentiment and Limits-to-Arbitrage on the Idiosyncratic Volatility Puzzle

수 있다. 이러한 관점에서 분석한 연구로는 Mitton and Vorkink(2007)가 있다. 이들은 개인 투자자는 현대 포트폴리오 이론에서 제시하는 잘 분산된 포트폴리오의 구성을 추구하는 대신, 고왜도 포트폴리오를 구성하려는 경향을 가진다는 것을 발견하였으며, 왜도와 주식수익률 사이에는 음(-)의 관계가 존재한다고 보고하였다. Kumar(2009)는 개인투자자들의 실제 거래 자료를 바탕으로 잡음 거래자의 거래행태를 분석하였다. 분석 결과, 잡음 거래자는 위험추구형 성향을 가지고 있으며 복권형 주식과 같은 고위험 주식을 선호하는 것으로 나타났다. 또한, 이러한 잡음 거래자의 거래행태는 상호 체계적인 상관관계를 가지므로 거래행태가 한 방향으로 몰려 해당 주가의 과잉반응을 야기한다고 주장하였다.

국내에도 고유변동성 이상현상을 잡음 거래자의 고왜도, 고위험 주식 선호 현상을 통해 설명하는 연구가 다수 존재한다. Kho and $\operatorname{Kim}(2014)$ 은 복권형 주식의 높은 왜도를 통해 고유변동성 이상현상을 설명하였는데, 이들은 고유변동성이 낮은 포트폴리오를 매수하고 고유변동성이 높은 포트폴리오를 매도하는 무비용 포트폴리오가 양(+)의 수익률을 얻는다는 결과를 제시하면서 한국 주식시장에 고유변동성 이상현상이 존재함을 증명하였다. 그리고 이러한 고유변동성 이상현상이 잡음 거래자들의 복권형 주식 선호에 기인한다는 것을 밝혀내기 위해, 고유변동성 포트폴리오의 수익률 특성을 분석하였다. 분석 결과, 과거 수익률의 왜도가 높은 주식일수록 잡음 거래자의 거래행태로 인한 과대평가가 심화되기 때문에, 과대평가된 가격오류가 수정되면서 미래의 기대수익률이 상대적으로 낮게 나타나는 것으로 밝혀졌다. 이는 잡음 거래자의 거래행태로 인해 왜도와 수익률 사이에는 음(-)의 관계가 존재한다는 주장을 지지하는 결과이다. $\operatorname{Sim}(2016)$ 역시 왜도와 수익률 간의 관계에 대해 연구하여, 왜도는 수익률과 음(-)의 관계에 있으며, 이러한 음(-)의 관계는 개인투자자의 거래 비중이 높은 주식일수록 강하게 나타난다고 보고하였다. 이는 잡음 거래자의 복권형 주식 선호에 의해 고왜도 주식의 기대수익률이 낮아진다는 것을 의미한다.

효율적 시장 가설에 의하면 잡음 거래자의 비합리적 거래행태로 가격오류가 발생하더라도, 차익거래자의 차익거래에 의해 가격오류는 즉시 수정되어 시장의 효율성을 유지한다. 그러나 실제 시장에서는 잡음 거래자에 의해 발생한 가격오류로 인해 차익거래 기회가 존재함에도 불구하고, 시장에 작용하고 있는 차익거래의 제약으로 인해 차익거래가 원활하게 이루어지지 않기 때문에, 차익거래를 통한 가격오류의 수정이 일어나지 않고 가격오류가 더욱 심화된다. 기존의 연구들은 이러한 차익거래의 제약이 시장에 보고되고 있는 $\mathrm{B} / \mathrm{M}$ 효과, 모멘텀 효과, 발생액 이상현상, 투자자산 증가 이상현상 등의 시장 이상현상을 심화시킨다는 연구 결과를 보고하고 있다. 최근에는 고유변동성 이상현상 역시, 차익거래 제약을 통해 분석하려는 시도가 이어져오고 있다. 차익거래 제약을 통해 고유변동성 이상현상을 설명하는 대표적인 연구로는 Stambaugh et al.(2015)의 연구가 있다. 이들은 고유변동성 이상현상의 원인을 시장의 차익거래 비대칭 현상을 통해 설명한다. 잡음 거래자에 의해 발생한 가격오류는 차익거래의 기회가 발생하였다는 것을 의미하는데, 이때, 차익거래자는 과소평가로 인한 가격오류가 발생한 주식은 매수하고, 과대평가로 인한 가격오류가 발생한 주식은 매도함으로써 주가가 내재가치를 반영하는 가격으로 수정될 수 있게 한다. 그러나 과소평가된 주식을 매수하는 것에는 특별한 제약이 
한국증권학회지 제49권 6호 (2020)

존재하지 않는 반면, 과대평가된 주식의 매도는 제약으로 인해 신속하게 이루어지지 못한다. 실제 시장에서는 공매도 거래를 하는 데 있어서 제약이 존재하며, 공매도 제약으로 인해 가격오류가 수정되지 않으므로 과대평가된 주식의 고유변동성은 수익률에 반영되지 않게 된다. Stambaugh et al.(2015)은 실증분석을 통해 과소평가된 주식으로 구성된 포트폴리오의 수익률은 고유변동성과 양(+)의 관계를 가지는 반면, 과대평가된 주식으로 구성된 포트폴리오의 수익률은 반대로 고유변동성과 음(-)의 관계를 가진다는 것을 밝혀내었다. 따라서 고유변동성과 수익률 간의 음(-)의 관계는 과대평가된 주식에 기인하는 것이며, 이는 고유변동성 이상현상이 시장의 미시구조적 장애요인에 의해 발생한 현상이라는 것을 의미한다.

한국 주식시장은 Stambaugh et al.(2015)이 분석한 미국 주식시장에 비해 공매도 제약 등 차익거래를 제약하는 요소가 상대적으로 강한 환경을 가지고 있다. 따라서 한국 주식시장의 고유변동성 이상현상을 차익거래 제약으로 설명하는 것은 의미 있는 시도라고 할 수 있다. $\operatorname{Eom}(2018)$ 은 주식시장의 횡단면 가격오류 측정치를 구성하여 과대평가된 주식과 과소평가된 주식을 구분하여 고유변동성 이상현상을 연구하였다. 연구 결과, 과소평가된 주식에서는 고유변동성과 수익률 간의 양(+)의 관계가 발견되는 반면, 과대평가된 주식에서는 음(-)의 관계가 발견되는 것으로 나타나, 고유변동성 이상현상은 과대평가된 주식으로 인해 발생한다는 이전의 연구들을 지지하는 근거를 제시하였다.

최근의 연구 중 $\mathrm{Gu}$ et al.(2018)은 중국 주식시장을 대상으로 차익거래 제약을 통한 고유변동성 이상현상에 관한 연구를 발표하였는데, 이들은 중국 주식시장이 가지고 있는 특성을 반영하는 변수들을 통해 차익거래 제약을 측정하였고, 이렇게 측정한 차익거래 제약이 높을수록 고유변동성 이상현상이 심화된다는 결과를 제시하였다. 한국 주식시장은 중국 주식시장과 마찬가지로 차익거래 제약이 상대적으로 강하게 나타나는 시장이므로, 한국 주식시장에서 고유변동성 이상현상을 설명하기 위해서는 기존의 선행연구에서 차익거래 제약을 나타내는 변수로 제시된 변수들과 한국 주식시장의 미시구조적 특성을 반영하는 변수들을 종합적으로 고려할 필요가 있다.

고유변동성 이상현상에 대한 국내연구들은 대부분 고유변동성 이상현상을 야기하는 특정 주식집단(저가주, 복권형 주식, 왜도가 유의한 양 $(+)$ 의 값을 지니는 주식 등)에 초점을 맞추고 있다. 본 연구는 먼저 투자자 심리와 차익거래 제약의 강도에 의하여 분류된 포트폴리오 수익률의 변동으로부터 고유변동성 이상현상을 야기하는 원인을 찾고자 한다. 다음으로 시간에 따른 고유변동성의 변화를 측정하고 비합리적인 거래행태를 보이는 투자자의 심리와 차익거래 제약으로 인한 차익거래 비대칭이 시간 가변적 고유변동성 이상현상에 미치는 영향을 관찰함 으로써 고유변동성 이상현상을 심화시키는 원인에 대해서 분석하도록 한다.

\section{3. 연구자료 및 연구설계}

\section{1 연구자료}

본 연구는 1992년 1월부터 2018년 12월까지 총 324개월 동안 한국 유가증권시장에 상장된 주식과 신규상장 주식, 상장폐지 주식의 월별수익률 $\left(R_{t}=\left(P_{t}-P_{t-1}\right) / P_{t-1}\right)$ 을 사용하여 분석을 
The Effects of Investor Sentiment and Limits-to-Arbitrage on the Idiosyncratic Volatility Puzzle

진행한다. 재무비율이 제조 업종 기업과 상이한 금융 업종 기업과 장부가치가 음(-)의 값을 가지는 자본잠식 상태의 기업은 표본에서 제외하며, 극단값에 의한 결과의 왜곡을 방지하기 위해 변수의 상위 $1 \%$ 와 하위 $1 \%$ 의 극단값은 절삭(truncation)한다. 또한, 재무제표자료의 이용에 있어서 실제 이용 가능 시점보다 앞서 자료를 이용함으로써 발생하는 사전관찰편향을 제거하기 위해 6 개월이 지연된 시점을 재무제표자료의 실제 이용 가능 시점으로 규정한다. 따라서 $t-1$ 년 12 월의 재무제표자료의 실제 자료 이용 가능 시점은 $t$ 년 7 월부터 $t+1$ 년 6 월까지이다. 분석에 사용되는 자료는 FnGuide와 한국은행경제통계시스템, 금융투자협회로부터 추출하였다. 본 연구에서 사용하는 개별기업의 수익률은 유·무상증자, 액면분할, 주식배당 등에 의한 단층 현상을 수정한 수정주가를 사용하여 계산한다. 시장수익률의 대리변수로 KOSPI 지수의 수익률을 사용하며, 무위험이자율의 대리변수로 통화안정증권 364일물 금리를 사용한다.

\section{2 연구설계}

Baker and Wurgler(2006)는 이전의 연구들에서 투자자 심리를 나타내는 척도로 보고된 개별변수들은 투자자 심리에 관한 요인뿐만 아니라 투자자 심리와 무관한 요인을 내포하고 있기 때문에, 각 개별변수에 내포되어있는 공통적인 투자자 심리 요인만을 추출하기 위해 주성분분석을 통한 하나의 지수를 구성할 것을 제안하였다. 따라서 본 연구에서도 투자자 심리와 차익거래 제약을 나타낸다고 보고된 변수들을 사용하여 주성분분석을 통해 투자자 심리 지수와 차익거래 제약 지수를 구성하도록 한다.

본 연구에서 투자자 심리 지수를 구성하는데 사용되는 변수는 상대강도지수, 현금흐름지수, 투자심리선, 개인투자자 순매수수량 비율, 투자자예탁금 증가율, 상장주식거래회전율, 신용융자 증가율, 소비자기대지수 증가율, 주식형펀드순자산 증가율, 주식발행비중의 10 개 변수이다 1 .

첫 번째 변수는 상대강도지수다. 상대강도지수는 시장의 과매수 또는 과매도 상태를 나타내는 지표로, 0 에서 100 사이의 값을 가지며 일반적으로 상대강도지수가 80 이상이면 과매수 상태를 의미하고, 20 이하면 과매도 상태를 의미한다. Chen et al.(2010)은 투자자의 시장에 대한 전망을 나타내는 변수로 상대강도지수를 포함한 6 개의 변수를 사용하여 구성한 투자자 심리 지수의 주식수익률에 대한 설명력을 분석하였다. 일반적으로 상대강도지수는 9 일 또는 14 일 기준으로 계산하며, 본 연구에서는 Chen et al.(2010)의 연구를 따라 14일 기준으로 산출한다.

두 번째 변수는 현금흐름지수다. 현금흐름지수는 시장에 매수를 위한 자금이 어느 정도 유입되었는지 또는 매도를 위한 자금이 어느 정도 유출되었는지를 나타내는 지표이다. 상대강도 지수와 마찬가지로 0 에서 100 사이의 값을 가지며, 주가의 추세를 반영하는 상대강도지수와 달리 주가의 추세와 거래량을 동시에 고려한 지표이다. 일반적으로 70 에서 80 이상의 값을 가지면 과매수 상태를 의미하고, 20에서 30 이하의 값을 가지면 과매도 상태를 의미한다. Chen et al.(2010) 등의 연구에서 투자자의 시장에 대한 전망을 나타내는 변수로 현금흐름지수를 포함한 6 개의 변수를 사용하여 구성한 투자자 심리 지수의 주식수익률에 대한 설명력을

1) 투자자 심리를 나타내는 변수의 측정 방법은 부록에 기재한다.

\section{8}


한국증권학회지 제49권 6호 (2020)

분석하였다. 현금흐름지수는 일반적으로 7 일 또는 14 일 기준으로 계산하며, 본 연구는 Chen et al.(2010)의 연구를 따라 14일 기준으로 산출한다.

세 번째 변수는 투자심리선이다. 투자심리선은 주식시장에서 나타나는 투자 심리의 변화를 포착하여 현재 시장의 투자 심리가 과매수 상태나 과매도 상태에 있는지를 나타내는 지표이다. 투자심리선은 0부터 100 사이의 값을 가지며, 일반적으로 투자심리선이 75 이상이면 과매수 상태를 의미하고 25 이하면 과매도 상태를 의미한다. Yang and Gao(2014)는 투자자 심리를 측정하는 척도로 투자심리선을 사용하여 분석을 진행하였다. 본 연구에서는 Yang and Gao (2014)의 연구에서 사용한 12 일 기준 투자심리선을 사용한다.

네 번째 변수는 개인투자자의 전체거래량에서 순매수수량이 차지하는 비율이다. 개인투자자의 거래행태에 대해 분석한 Odean(1999)의 연구에 의하면, 개인투자자들은 이전의 수익률이 높은 주식을 매수하는 경향을 보이며, 자신이 보유하고 있는 주식의 수익률이 하락하는 경우에는 해당 주식을 추가로 매수하는 경향을 가진다. Odean(1999) 등의 연구에서 보고한 것과 같이 개인투자자의 거래는 상대적으로 시장 상황에 대한 심리적인 영향을 많이 받는다. 따라서 개인투자자의 순매수수량이 개인투자자의 전체거래량에서 차지하는 비율이 높다는 것은 시장을 낙관적으로 전망하고 있다는 의미이다. 반대로 개인투자자의 순매수수량 비율이 감소한다는 것은 시장에 대한 전망이 비관적으로 돌아서고 있다고 해석할 수 있다. Kumar and Lee(2006)는 개인투자자의 거래 자료를 이용하여 산출한 개인투자자 순매수수량 비율을 투자자 심리의 척도로 제시하면서, 개인투자자 순매수수량 비율은 다른 변수들을 통제한 후에도 주식수익률에 대한 설명력을 가진다고 주장하였다.

다섯 번째 변수는 투자자예탁금의 증가율이다. 투자자예탁금은 투자자가 주식 매입을 위해 증권사에 예탁해놓은 자금으로, 투자자예탁금의 증가는 매수를 위한 자금의 유입을 의미하며 투자자예탁금의 감소는 자금의 유출을 의미한다. Kim and Byun(2010)은 투자자예탁금의 증가는 투자자가 주식시장에 대해 낙관적으로 전망하고 있다는 것을 의미하므로, 투자자예탁금은 투자자 심리를 나타내는 척도라고 보고하였다. Kim and Byun(2010)에 따르면 투자자예탁금은 시간에 따라 증가하는 추세를 가지므로, 본 연구에서는 투자자예탁금의 추세를 제거하기 위해 $\mathrm{Kim}$ and Byun(2010)이 제시한 방법에 따라 당월의 투자자예탁금에서 이전 24개월의 이동평균을 차감한 값을 당월의 투자자예탁금으로 나누어서 계산한다.

여섯 번째 변수는 상장주식거래회전율이다. 주식시장에서 잡음 거래자들은 개인의 인지적 편향에 의한 거래 활동으로 주가를 내재가치에서 벗어나게 하는 가격오류를 유발한다는 사실은 Odean(1998) 등의 연구에서 밝혀진 바 있다. 이러한 잡음 거래자들은 특히 주가에 대한 긍정적인 정보에 과잉반응하며, 이는 곧 주가의 과대평가와 거래량의 증가를 가져온다. 반면, 주가에 대한 부정적인 정보가 유입된 경우에는, 공매도 제약 때문에 부정적인 정보를 이용한 거래는 제한적으로 이루어질 수밖에 없으므로 거래량은 감소하게 된다. 따라서 주식시장에서 거래량의 증가는 시장에 대한 투자자의 전망이 낙관적이라는 것을 의미하며, 거래량의 감소는 투자자가 시장을 비관적으로 전망하고 있다는 의미가 된다. 상장주식거래회전율은 유동성을 나태는 지표로 상장주식거래회전율이 높다는 것은 투자자들이 시장에 대해서 긍정적으로 전망한다는 의미이다. 
The Effects of Investor Sentiment and Limits-to-Arbitrage on the Idiosyncratic Volatility Puzzle

Baker and Stein(2004)은 시장의 유동성을 측정하는 척도로 상장주식거래회전율을 사용하여 분석하였다. 분석 결과, 상장주식거래회전율의 상승은 과대평가에 기인한 투자자 심리를 반영하는 것으로 나타났다. 본 연구에서는 유동성의 증가가 투자자의 낙관적인 전망에서 기인한 것인지, 아니면 비관적인 전망에서 기인한 것인지 구분하기 위해 Yang and Zhang(2014) 등에서 사용한 수정된 상장주식거래회전율을 사용한다. 또한, 상장주식거래회전율의 추세를 제거하기 위해 Baker and Stein(2004)의 방법을 따라 이전 60개월의 이동평균을 차감하여 계산한다.

일곱 번째 변수는 신용융자 증가율이다. 신용융자는 개인투자자들이 주식 거래를 위해 타 기관에서 차입한 자금의 규모를 보여준다. 따라서 신용융자의 증가는 개인투자자들의 주식시장에 대한 전망이 긍정적이라는 것을 의미하며, 반대로 신용융자의 감소는 주식시장에 대한 부정적인 전망을 나타낸다. Nam and Park(1996)은 신용융자 잔고를 사용하여 주식수익률에 대한 예측력을 분석하였다. Nam and Park(1996)에 따르면 신용융자를 통해 거래하는 투자자들은 주가에 대한 정보를 이용하여 거래하는 정보거래자에 비해 상대적으로 낮은 위험회피성향을 가지고 있다. 이러한 결과는 신용융자가 주식시장에서 투자자의 심리를 나타내는 변수가 될 수 있다는 것을 의미한다.

여덟 번째 변수는 소비자기대지수 증가율이다. 소비자기대지수는 6 개월 후 경기에 대해 소비자들이 가지고 있는 기대심리를 설문조사를 사용하여 측정한 지표이다. 소비자기대지수가 높다는 것은 경기를 긍정적으로 평가한다는 의미이고, 낮다는 것은 경기를 부정적으로 평가한다는 의미이다. Brown and Cliff(2004)는 설문조사를 통해 측정한 투자자 심리 지수를 사용하여 투자자 심리가 주식수익률에 미치는 영향을 분석하였고, Fisher and Statman(2003)의 연구 에서도 소비자기대지수를 투자자 심리를 측정하는 척도로 사용하여 분석을 진행하였다. 본 연구에서는 매월 통계청에서 발표하는 소비자기대지수를 사용하여 분석을 진행한다.

아홉 번째 변수는 주식형펀드순자산 증가율이다. Frazzini and Lamont(2008)에 따르면 개인투자자들이 펀드 간의 자금을 이전 할 때는 경제 전망을 고려하기 때문에, 개인투자자들의 펀드 간 자금흐름은 개인투자자들의 투자 심리를 나타낸다. Frazzini and Lamont(2008)는 주식형펀드의 자산 증가를 투자자 심리 변수로 사용하여 분석한 결과, 개인투자자의 거래가 집중된 펀드에 포함되어있는 주식들의 가격은 과대평가되는 경향이 있다고 보고하였다. 즉, 주식형펀드순자산이 증가한다는 것은 투자자들이 시장의 전망을 긍정적으로 보고 있다는 의미이고, 감소한다는 것은 투자자들이 시장의 전망을 부정적으로 보고 있다는 의미이다.

마지막으로 사용할 변수는 기업의 전체 자금조달금액 중 주식발행으로 조달한 금액의 비중을 나타내는 주식발행비중이다. Baker and Wurgler(2000)는 기업의 자금조달금액에서 주식발행이 차지하는 비중이 높다는 것은 투자자들이 시장을 긍정적으로 평가한다는 것을 나타내며, 주식발행 비중이 낮다는 것은 시장을 부정적으로 평가하고 있다는 것을 나타내므로, 주식발행비중은 투자자 심리를 반영하는 척도라고 하였다. 또한, Baker and Wurgler(2006)는 투자자 심리가 주식수익률에 미치는 영향을 분석하기 위해 주식발행비중을 포함한 변수들로 투자자 심리 지수를 구성하여 분석을 진행하였다.

이상의 10 개의 투자자 심리 변수를 사용하여 투자자 심리 지수를 구성한다. 먼저, 개별 투자자 심리 변수들이 선행지표인지 동행지표인지 구분하기 위해 10 개의 투자자 심리 변수와 각 변수의 
한국증권학회지 제49권 6호 (2020)

1 시차 전기 변수를 합친 총 20 개 변수를 사용하여 1 차 주성분분석을 시행한다. 이렇게 1 차 주성분분석을 통해 추출된 제 1 주성분과 20 개 변수간의 상관관계를 측정하여 상관관계가 높은 시차의 변수를 투자자 심리 지수에 사용할 변수로 결정한다. 주성분분석 결과에 따르면 상대강도지수, 투자자예탁금 증가율, 소비자기대지수 증가율, 주식발행비중은 동 시차의 변수가 제 1 주성분과의 상관관계가 높은 것으로 나타났고, 현금흐름지수, 투자심리선, 개인투자자 순매수수량 비율, 상장주식거래회전율, 신용융자 증가율, 주식형펀드순자산 증가율은 1 시차 전기 변수가 제 1 주성분과의 상관관계가 높은 것으로 나타났다. 이렇게 결정된 10 개의 투자자 심리 변수를 사용하여 다시 2 차 주성분분석을 시행하여, 2 차 주성분분석을 통해 추출된 제 1 주성분을 투자자 심리 지수로 측정한다. <표 1>은 주성분분석으로 구성한 투자자 심리 지수와 지수를 구성하는 데 사용한 10 개의 투자자 심리 변수 간의 상관관계를 보여준다. <표 $1>$ 에 따르면 투자자 심리 지수는 주식발행비중을 제외한 나머지 9 개 변수와는 $1 \%$ 수준에서 유의한 상관관계를 가지며, 주식발행비중과는 $5 \%$ 수준에서 유의한 상관관계를 가지는 것으로 나타났다. 이는 투자자 심리 지수가 변수들에 내포되어있는 공통적인 투자자 심리 요인을 잘 반영하고 있다는 결과로 볼 수 있다.

본 연구에서는 투자자 심리 지수와 더불어 차익거래 제약 지수를 구성하여 분석을 진행한다. 주식시장에서 공통적으로 나타나는 차익거래 제약 변수인 변동성 지수, TED 스프레드, 신용 스프레드, 호가 스프레드, 비유동성, 주식거래량, 투자의견빈도와 함께 한국 주식시장의 특성을 반영하는 변수인 가격제한폭과 공매도 거래를 사용하여 분석을 진행하도록 한다.2)

차익거래 제약 분석에 사용하는 첫 번째 변수는 변동성 지수다. Gromb and Vayanos(2002)의 연구에 따르면 시장의 변동성 증가는 차익거래자가 자금을 조달하는 데 있어서 제약을 증가시킨다. Shleifer and Vishny(1997)는 시장의 변동성이 증가하면 투자자들은 시장에 유입된 자금을 회수하려고 하며, 이는 차익거래자로 하여금 포지션의 청산을 강제하게 된다고 하였다. 따라서 시장의 변동성 증가는 차익거래 제약의 증가를 의미한다. Jacobs(2015)는 VIX(Chicago board options exchange market volatility index)를 변동성 지수로 사용하여 미국 주식시장에 존재하는 이상현상에 대한 설명력을 분석한 결과, 변동성 지수는 다양한 시장 이상현상에 대해 설명력을 가지는 것으로 나타났다고 보고하였다. 본 연구에서는 시장의 변동성을 나타내는 변동성 지수로 한국거래소에서 산출하여 발표하는 VKOSPI를 사용한다. VKOSPI는 KOSPI200옵션 최근월물과 차근월물을 대상으로 공정분산스왑 방식3)으로 산출한다. 분석에 사용하는 VKOSPI 자료는 한국거래소에서 자료를 제공하기 시작한 2003년 1월 2일부터는 한국거래소에서 발표하는 자료를 사용하고, 그 이전 시점은 직접 계산하여 측정한 자료를 사용한다. VKOSPI는 KOSPI200옵션의 최근월물 잔존기간을 기준으로 잔존기간이 30 일 미만인 경우에는 최근월물 변동성과 차근월물 변동성으로부터 내삽하여 계산하며, 잔존기간이 30 일 이상인 경우에는 거래의 대부분이 최근월물에 집중되므로 최근월물 변동성만 사용하여 계산한다.

2) 차익거래 제약을 나타내는 변수의 측정 방법은 부록에 기재한다.

3) 분산스왑의 현재가치를 0 으로 만드는 공정분산의 제곱근을 변동성 지수로 사용한다. 이러한 공정분산은 투자자들이 기대하는 현재부터 만기까지의 기초자산의 변동성을 의미한다. 
The Effects of Investor Sentiment and Limits-to-Arbitrage on the Idiosyncratic Volatility Puzzle

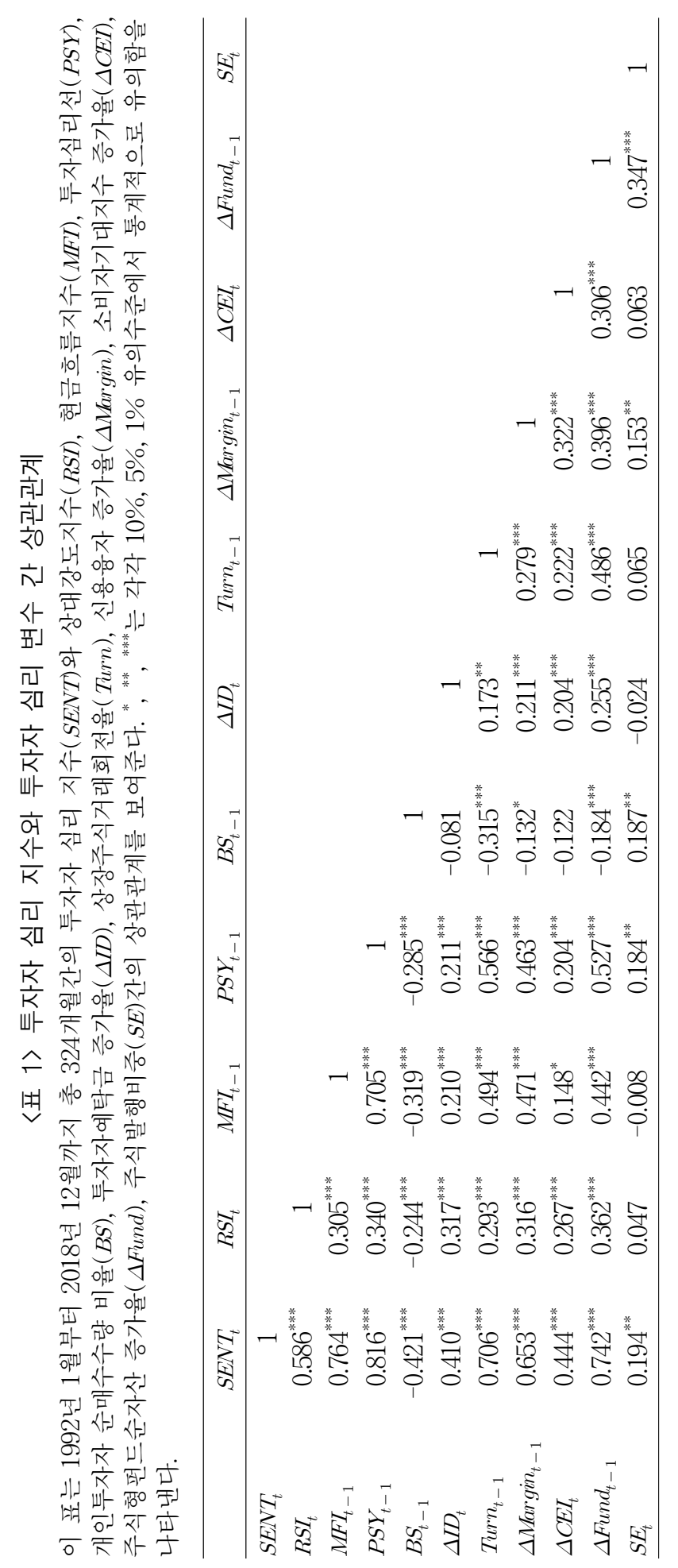


한국증권학회지 제49권 6호 (2020)

두 번째 변수는 TED 스프레드다. 시장에 대한 비관적인 신호가 관찰되면 투자자들은 주식에 투자한 자금을 채권이나 현물과 같은 위험이 낮은 자산으로 이동시키는 안전자산선호(flightto-quality) 경향을 보인다. 주식에서 안전자산으로의 자금 이동은 주식시장의 유동성 저하를 유발할 수 있다. Ang et al.(2011)은 TED 스프레드를 사용하여 자금조달의 유동성을 측정하였고, $\mathrm{TED}$ 스프레드의 확대는 자금경색을 유발하며 이는 곧 차익거래 제약의 증가를 의미한다고 보고하였다. Jacobs(2015)는 차익거래 제약을 측정하는 척도로 TED 스프레드를 사용하여, $\mathrm{TED}$ 스프레드가 시장 이상현상에 대해 설명력을 가진다고 주장하였다. 본 연구에서는 한국 주식시장에 적합한 $\mathrm{TED}$ 스프레드를 산출하기 위해, 한국의 은행 간 대차시장 기준금리인 1 년만기 KORIBOR(Korea inter-bank offer rate)에서 1년만기 국채수익률을 차감하여 TED 스프레드를 측정한다.

세 번째 변수는 신용 스프레드다. Jacobs(2015)는 신용 스프레드의 확대는 시장의 자금경색을 나타내는 척도라고 설명하면서, TED 스프레드와 함께 신용 스프레드를 차익거래 제약을 측정하는 척도로 사용하였고, 신용 스프레드가 시장 이상현상에 대해 유의한 설명력을 가진다는 결과를 보고하였다. 본 연구에서는 금융투자협회에서 제공하는 3년만기 $\mathrm{BBB}$-회사채금리와 3 년만기 $\mathrm{AA}$-회사채금리의 차이를 신용 스프레드로 정의한다.

네 번째 변수는 호가 스프레드다. 호가 스프레드는 최우선 매수호가와 최우선 매도호가의 차이를 나타내는 지표이다. 즉시 매수를 원하는 경우, 투자자는 최우선 매도호가에 거래하게 되고, 매도를 원하는 경우에는 최우선 매수호가에 거래하게 된다. Kim and Verrecchia(1994)에 따르면 투자자들이 이용할 수 있는 정보가 많을수록 해당 기업에 대한 유동성은 증가하고 호가 스프레드는 줄어든다. 반대로, 해당 기업에 대한 정보가 부족한 정보비대칭 현상이 발생하면 해당 기업에 대한 호가 스프레드는 확대되고 이는 유동성 저하로 인한 거래비용의 증가로 이어지므로, 호가 스프레드의 확대는 차익거래 제약의 증가를 의미한다. Chordia et al.(2008)은 호가 스프레드가 증가할수록 시장의 비효율성이 증가한다고 하였고, Jacobs(2015)는 호가 스프레드를 거래비용을 나타내는 척도로 사용하여 차익거래 제약이 시장에 존재한다고 알려진 이상현상에 대해 유의한 설명력을 가진다고 보고하였다. 본 연구에서는 Corwin and Schultz(2012)에서 제시한 방법에 따라 일중 최고가와 일중 최저가의 차이를 호가 스프레드로 계산한다.

다섯 번째 변수는 비유동성이다. Sadka and Scherbina(2007)는 유동성의 감소는 차익거래의 거래비용을 증가시켜, 가격오류가 발생한 주식이 차익거래를 통해 가격오류가 수정되는 것을 막는다고 하였다. 다시 말해 유동성의 감소는 거래비용의 증가를 가져오며 이는 차익거래 제약이 강해졌음을 뜻한다. 본 연구에서는 유동성의 감소를 나타내기 위한 척도로 Lou and Shu(2017) 에서 제시한 비유동성 지표를 사용한다.4)

여섯 번째 변수는 주식거래량이다. Mashruwala et al.(2006)에 따르면 주식거래량의 증가는 거래비용을 감소시킬 뿐만 아니라, 차익거래자가 거래상대를 찾는 것을 용이하게 함으로써

4) Lou and Shu(2017)는 Amihud(2002)에서 제시한 비유동성 지표의 횡단면적 설명력은 대부분 거래대금에 기인하는 것이고, 일별수익률의 절대값은 큰 영향을 주지 못한다고 주장하였다. 
The Effects of Investor Sentiment and Limits-to-Arbitrage on the Idiosyncratic Volatility Puzzle

차익거래를 촉진시킨다. 반대로 주식거래량이 감소한다면 거래비용이 증가하고 차익거래자가 차익거래를 하는 데 있어서 어려움을 겪을 것이다. 따라서 주식거래량의 감소는 차익거래 제약의 증가를 의미한다. $\mathrm{Gu}$ et al.(2018)은 차익거래 제약을 측정하기 위한 척도로 주식거래량을 사용하여 분석한 결과, 주식거래량을 포함한 6 개의 변수로 구성한 차익거래 제약 지수는 고유변동성 이상현상에 대해 유의한 설명력을 가지는 것으로 나타났다고 보고하였다.

일곱 번째 변수는 투자의견의 빈도다. Hong et al.(2000)에 따르면 애널리스트의 투자의견 빈도가 낮은 기업은 정보가 투자자들에게 느리게 전달되고, 이는 투자의견 빈도가 낮을수록 거래비용이 증가한다는 것을 의미한다. 거래비용의 증가는 차익거래 제약의 증가를 뜻하므로 투자의견빈도는 차익거래 제약을 나타내는 변수이다. Gu et al.(2018)은 차익거래 제약 지수를 구성하는 변수로 투자의견빈도를 사용하여 분석하였다. 애널리스트가 해당 기업에 낸 투자의견의 숫자가 해당 월의 중앙값보다 낮으면 1 , 높으면 0 의 값을 부여하여 투자의견빈도가 낮을수록 차익거래 제약이 큰 기업으로 분류한다. 분석 결과, 투자의견빈도를 포함한 변수들로 구성한 차익거래 제약 지수는 시장 이상현상에 대한 설명력을 가지는 것으로 나타났다. 본 연구에서는 애널리스트의 투자의견빈도의 증가율을 사용하여 분석을 진행한다.

여덟 번째 변수는 한국 주식시장의 가격제한폭이다. 가격제한폭은 주가의 급격한 상승이나 하락으로 인해 주식시장에 큰 충격이 가해지는 것을 방지하기 위해 도입된 장치이다. 가격제한폭의 도입을 지지하는 측은 가격제한폭이 시장의 변동성을 감소시키고 시장의 과잉반응을 억제하면서도 거래를 제한하지 않는다고 주장한다. 그러나 Kim and Rhee(1997)의 연구에 따르면 가격제한폭에 도달한 주식의 변동성은 그렇지 않은 주식의 변동성에 비해 정상 수준의 변동성을 회복하는 것이 느리며, 가격의 연속성 역시 가격제한폭에 도달한 주식이 그렇지 않은 주식에 비해 더 자주 일어난다. 또한, 가격제한폭은 차익거래 활동을 제한함으로써 가격오류를 수정하여 균형 가격으로 회귀하는 것을 지연시킨다. Chan et al.(2005)은 가격제한폭은 도입된 목적과 다르게 정보비대칭을 개선하지 못하고 오히려 차익거래자의 활동을 제한하여 가격오류의 수정을 지연시킨다고 주장하였다. 따라서 가격제한폭에 도달하는 횟수가 많을수록 차익거래 제약은 증가한다. 본 연구에서는 해당 월에 속한 일별 가격이 가격제한폭에 도달한 횟수로 가격제한폭을 측정한다.

차익거래 제약 분석에 사용하는 마지막 변수는 공매도 체결과 공매도 잔고금액이다. 일반적으로 주식 거래에 있어서 특정 종목의 매수는 제약 없이 실행할 수 있지만, 매도를 하기 위해서는 해당 종목을 보유하고 있어야 한다. 이는 매수에 대한 정보는 시장에 신속하게 반영되는 반면, 매도에 대한 정보의 반영은 충분하지 못하다는 의미가 된다. 공매도는 이러한 정보 반영의 불균형을 해소해주는 역할을 하며, 공매도 제도의 기본적인 도입 취지는 주식시장에서 유동성을 확대하여 시장의 효율성을 높이는 데 있다. Saffi and Sigurdsson(2011)의 연구에 따르면 공매도가 활성화되어있는 주식시장이 그렇지 않은 주식시장에 비해 시장의 효율성이 높으며, 이는 공매도가 주식시장의 유동성을 증가시킴으로써 시장의 효율성을 향상시킨 결과이다. 주식시장에서 공매도의 또 다른 역할은 가격발견기능이다. 즉, 비합리적인 투자자들의 과잉반응으로 인해 특정 주식이 과대평가되어 가격오류가 발생하였을 때, 공매도는 차익거래자들의 매도 
한국증권학회지 제49권 6호 (2020)

거래를 용이하게 함으로써 가격오류의 수정을 촉진하는 역할을 한다. Diamond and Verrecchia (1987)에 따르면 공매도 거래는 일반 거래에 비해 많은 규제를 받고 있기 때문에, 이러한 거래비용을 감수하면서 공매도를 거래하는 공매도거래자들은 주가에 대한 확실한 정보를 가지고 있는 정보거래자일 가능성이 높다. 이러한 정보거래자들의 거래는 주가에 대한 많은 정보를 반영하고 있기 때문에, 공매도는 가격오류를 수정하고 주가의 내재가치를 회복하게 하는 가격발견기능의 역할을 한다. 한국 주식시장의 공매도 거래는 대차거래를 통한 차입 공매도이므로, 본 연구에서는 공매도 거래를 측정하는 척도로 대차거래 체결과 대차거래 잔고를 사용한다.

차익거래 제약 지수를 구성하기 위해서는 구성에 사용되는 변수들이 차익거래 제약에 대한 선행지표인지 동행지표인지를 먼저 파악해야 한다. 따라서 10 개의 동 시차 차익거래 제약 변수와 각 변수의 1 시차 전기 변수를 합친 총 20 개의 변수를 대상으로 1 차 주성분분석을 시행하여 20 개 변수에 공통적으로 포함되어 있는 제 1 주성분을 추출한다. 이렇게 추출한 제 1 주성분과 20 개 변수 간의 상관관계를 분석하여, 동 시차 변수의 상관관계가 높다면 동행지표, 1 시차 전기 변수의 상관관계가 높다면 선행지표를 차익거래 제약 지수를 구성하는 데 사용한다. 주성분분석 결과에 따르면, TED 스프레드, 신용 스프레드, 비유동성, 주식거래량, 공매도 거래, 공매도 잔고는 동 시차 변수가 1 시차 전기 변수보다 제 1 주성분과의 상관관계가 높게 나타나므로 동행지표인 것으로 확인되었다. 반면, 변동성 지수, 호가 스프레드, 투자의견빈도, 가격제한폭은 1 시차 전기 변수의 상관관계가 동 시차 변수보다 높게 나타나므로 선행지표인 것을 알 수 있다. 차익거래 제약 지수의 구성에 필요한 변수의 결정이 끝나면, 2 차 주성분분석을 시행하여 차익거래 제약 지수를 구성한다. 주성분분석을 통해 10 개 변수에 공통적으로 내포되어있는 제 1 주성분을 추출하여 차익거래 제약 지수를 측정한다. <표 $2>$ 는 주성분분석을 통해 구성한 차익거래 제약 지수와 주성분분석에 사용한 10 개의 차익거래 제약 변수 간의 상관관계를 제시한다. <표 $2>$ 에 의하면 차익거래 제약 지수는 10 개의 차익거래 제약 변수 중 7 개의 변수와 $1 \%$ 수준에서 유의한 상관관계를 가지는 것으로 나타났으므로, 차익거래 제약 변수들이 공통적으로 내포하고 있는 차익거래 제약 요인을 반영하여 지수가 구성되었음을 알 수 있다.

한편, $\mathrm{Kim}$ and $\mathrm{Na}$ (2018)는 기존의 연구에서 투자자 심리 지수와 차익거래 제약 지수를 사용하여 분석한 결과는 거시경제변수의 영향을 모두 제거하지 못한 데 따른 결과일 수 있으므로, 거시경제변수의 영향을 완전히 제거한 지수를 구축해야 정확한 결과를 도출할 수 있다고 주장하였다. 이들은 투자자 심리와 차익거래 제약은 거시경제변수에 민감하게 반응하므로 전체기간에 대하여 단 한 번 회귀계수를 추정하기보다는 통계적 안정성을 고려한 순차이동 회귀분석(rolling regression)을 시행하여야 하며, 순차이동 회귀분석을 통해 측정된 잔차를 투자자 심리 지수와 차익거래 제약 지수로 사용해야 정확한 결과를 얻을 수 있다고 주장하였다. 따라서 본 연구는 투자자 심리 지수와 차익거래 제약 지수에서 거시경제변수의 영향을 완전히 제거하기 위하여, $\mathrm{Kim}$ and $\mathrm{Na}$ (2018)에서 제시한 방법에 따라 식 (1)을 과거 60개월의 표본구간에 대해 회귀하여 회귀계수를 추정한 후, 추정된 회귀계수를 통해 측정한 잔차를 투자자 심리 지수와 차익거래 제약 지수로 사용한다. 회귀분석에 사용되는 거시경제변수는 장단기금리차, 신용 스프레드, 단기이자율, 인플레이션율이다. 
The Effects of Investor Sentiment and Limits-to-Arbitrage on the Idiosyncratic Volatility Puzzle

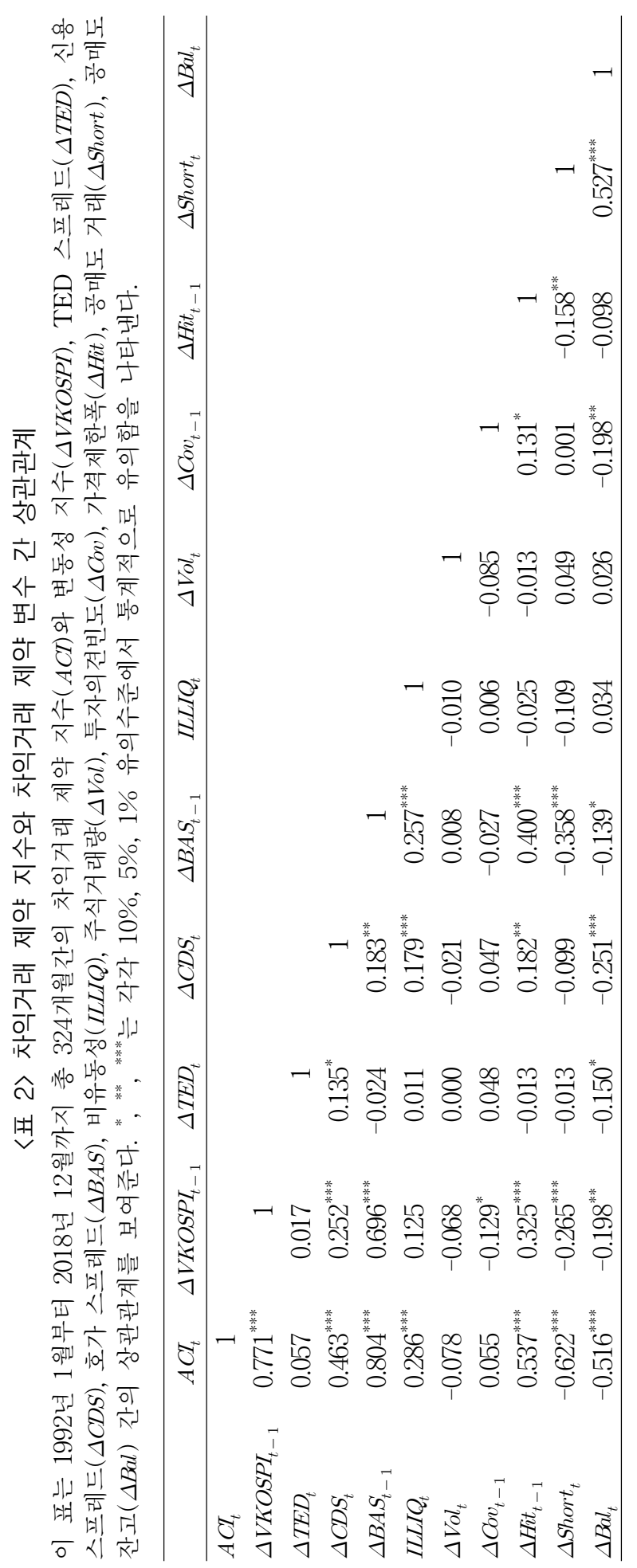


한국증권학회지 제49권 6호 (2020)

$$
\text { Index }_{t}=\alpha_{i}+\beta_{\text {Term }} \text { Term }_{t-1}+\beta_{C D S} C D S_{t-1}+\beta_{R F} R F_{t-1}+\beta_{I n f} \operatorname{Inf} f_{t-1}+\epsilon_{t}
$$

Index: $t$ 기의 투자자 심리 지수 또는 차익거래 제약 지수

$\alpha_{i}$ : 상수항

$\beta_{\text {Term }}, \beta_{C D S}, \beta_{R F}, \beta_{I n f}$ : 각 변수별 회귀계수

$\operatorname{Term}_{t-1}: t-1$ 기의 장단기금리차

$C D S_{t-1}: t-1$ 기의 신용 스프레드

$R F_{t-1}: t-1$ 기의 단기이자율

$m f_{t-1}: t-1$ 기의 인플레이션율

$\epsilon_{t}$ : 잔차

다음으로 고유변동성 추정과정을 설명한다. 본 연구에서는 Ang et al.(2006)의 방법론에 따라 Fama and French(1993)가 제시한 3요인 모형을 이용하여 해당 월에 속해있는 거래일의 일별수익률에 대한 잔차를 추정한다. 잔차 추정에 사용하는 Fama-French 3요인 모형의 위험요인 모방포트폴리오는 다음과 같이 구성한다. 먼저 $t$ 년 6 월 말에 측정한 기업규모를 크기순으로 정렬하여 하위 $50 \%$ 기업규모 포트폴리오 $(\mathrm{S})$, 상위 $50 \%$ 기업규모 포트폴리오(B)를 구성한다 그리고 $t-1$ 년 12 월 말의 $\mathrm{B} / \mathrm{M}$ 을 기준으로 상위 $30 \%$ 포트폴리오 $(\mathrm{H})$, 중위 $40 \%$ 포트폴리오(M), 하위 $30 \%$ 포트폴리오(L)를 구성한다. 그다음, 2 개의 기업규모 포트폴리오와 3 개의 $\mathrm{B} / \mathrm{M}$ 포트폴리오를 교차시켜서 총 6개의 포트폴리오( $\mathrm{SH}, \mathrm{SM}, \mathrm{SL}, \mathrm{BH}, \mathrm{BM}, \mathrm{BL}$ )를 구성한 후, 소규모-B/M 포트폴리오(SH, SM, SL)의 평균수익률에서 대규모-B/M 포트폴리오(BH, $\mathrm{BM}$, $\mathrm{BL})$ 의 평균수익률을 차감하여 규모요인 모방포트폴리오(SMB)를 구성한다. 가치요인 모방 포트폴리오는 높은 $\mathrm{B} / \mathrm{M}$ 포트폴리오 $(\mathrm{SH}, \mathrm{BH})$ 의 평균수익률에서 낮은 $\mathrm{B} / \mathrm{M}$ 포트폴리오( $\mathrm{SL}$, $\mathrm{BL})$ 의 평균수익률을 차감하여 계산한다. 다음으로, 추정한 일별 잔차의 표준편차를 계산하여 해당 월의 고유변동성으로 정의한다. 고유변동성을 측정하는 식은 다음과 같다.

$$
\begin{aligned}
& R_{i, d, t}-R_{f, d, t}=\alpha_{i}+\beta_{R M R F} R M R F_{d, t}+\beta_{S M B} S M B_{d, t}+\beta_{H M L} H M L_{d, t}+\epsilon_{i, d, t} \\
& I V O L_{i, t}=\sqrt{\sigma\left(\epsilon_{i, d, t}\right)^{2}}
\end{aligned}
$$

$R_{i, d, t}: t$ 월의 $d$ 일의 개별기업 $i$ 의 수익률

$R_{f, d, t}: t$ 월의 $d$ 일의 무위험이자율

$I V O L_{i, t}: t$ 월의 개별기업 $i$ 의 고유변동성

$\alpha_{i}$ : 상수항

$\beta_{R M R F}, \beta_{S M B}, \beta_{H M L}$ : 각 요인별 요인민감도

$R M R F_{d, t}: t$ 월의 $d$ 일의 시장요인

$S M B_{d, t}: t$ 월의 $d$ 일의 규모요인

$H M L_{d, t}: t$ 월의 $d$ 일의 가치요인

$\epsilon_{i, d, t}: t$ 월의 $d$ 일의 잔차 
The Effects of Investor Sentiment and Limits-to-Arbitrage on the Idiosyncratic Volatility Puzzle

투자자 심리와 차익거래 제약이 고유변동성 이상현상에 미치는 영향을 분석하기에 앞서, Ang et al.(2006)이 보고한 고유변동성 이상현상이 한국 주식시장에서 발견되는지 검증하기 위해 10 분위 고유변동성 포트폴리오를 구성하여 분석을 시행한다. 고유변동성 포트폴리오 구성 방법은 다음과 같다. 앞서 측정한 고유변동성을 사용하여 고유변동성이 낮은 순서대로 10 개의 주식집단을 분류하여 고유변동성 10분위 포트폴리오를 구성하고, 구성한 포트폴리오의 동일가중 수익률과 가치가중수익률을 계산한다. 또한, 포트폴리오의 수익률은 무위험이자율에 대한 초과수익률과 Fama-French 3요인 모형을 이용하여 산출한 알파값 $(\alpha)$ 으로 측정한 위험조정 수익률의 2 가지 수익률로 제시하도록 한다.

다음으로, 투자자 심리와 차익거래 제약이 고유변동성 이상현상에 미치는 영향을 분석하기 위해 투자자 심리-고유변동성 포트폴리오와 차익거래 제약-고유변동성 포트폴리오를 구성한다. 투자자 심리-고유변동성 포트폴리오의 구성 방법은 다음과 같다. 앞서 주성분분석을 사용하여 구성한 투자자 심리 지수를 사용하여 투자자 심리 지수가 낮은 순서대로 3개의 포트폴리오를 구성한다. 그리고 구성한 3 개의 포트폴리오마다 포트폴리오에 포함된 주식을 고유변동성이 낮은 순서로 정렬하여 1 개의 투자자 심리 포트폴리오 당 5 개의 고유변동성 포트폴리오를 구성하여 총 15 개의 포트폴리오를 구성한다. 15 개의 포트폴리오의 동일가중수익률과 가치가중수익률을 계산하여 최종적으로 15 개의 투자자 심리-고유변동성 동일가중 포트폴리오와 15 개의 투자자 심리-고유변동성 가치가중 포트폴리오를 구성한다. 포트폴리오의 수익률은 무위험이자율에 대한 초과수익률과 Fama-French 3요인 모형을 이용하여 산출한 알파값으로 측정한 위험조정 수익률의 2 가지 수익률을 사용한다. 차익거래 제약-고유변동성 포트폴리오는 차익거래 제약 지수가 낮은 순서대로 3 개의 포트폴리오를 구성하여, 각 포트폴리오에 포함된 주식을 고유 변동성이 낮은 순서로 정렬하여 다시 포트폴리오마다 5개의 고유변동성 포트폴리오를 구성한다. 이렇게 하여 총 15 개의 포트폴리오를 구성하며, 각각 동일가중수익률과 가치가중수익률을 계산하여 최종적으로 15 개의 차익거래 제약-고유변동성 동일가중 포트폴리오와 15 개의 차익거래 제약-고유변동성 가치가중 포트폴리오를 대상으로 분석을 시행한다. 포트폴리오의 수익률은 무위험이자율에 대한 초과수익률과 Fama-French 3요인 모형을 사용하여 산출한 알파값으로 측정한 위험조정수익률로 제시한다.

마지막으로, 본 연구에서는 차익거래 제약이 고유변동성 이상현상에 미치는 영향을 보다 강건하게 검증하기 위해 Fama and Macbeth(1973)에서 제시한 횡단면 회귀분석을 시행한다. 종속변수는 월별 주식수익률에서 월별 무위험이자율을 차감한 개별기업의 월별 초과수익률이며 독립변수는 일별 주식수익률에 대해 Fama-French 3요인 모형을 회귀시켜 나온 잔차의 표준편차로 측정한 고유변동성이다. 고유변동성 이상현상에 대한 차익거래 제약의 영향을 검증하기 위해 차익거래 제약 지수가 낮은 순서대로 3 개의 포트폴리오를 구성하여, 차익거래 제약이 가장 낮은 포트폴리오의 고유변동성, 차익거래 제약이 중간인 포트폴리오의 고유변동성, 차익거래 제약이 가장 높은 포트폴리오의 고유변동성을 각각 독립변수로 하여 분석을 진행한다. 또한, 기업규모, 장부가치 대 시장가치 비율, 상장주식거래회전율과 같은 기업특성변수와 월중 
일별수익률이 가장 높은 상위 5 개 거래일의 평균수익률로 측정한 일별 최고수익률5)을 통제변수로 사용한다. 분석에 사용되는 모형은 다음과 같다.

$$
\begin{aligned}
& R_{i, t}-R_{f, t}=\alpha_{i}+\gamma_{1} I V O L_{i, t-1}+\gamma_{2} \ln \text { Size }_{i, t-1}+\gamma_{3} \ln B / M_{i, t-1}+\gamma_{4} \text { Turn }_{i, t-1}+\gamma_{5} \operatorname{Max}_{i, t-1}+\epsilon_{i, t} \\
& R_{i, t}: t \text { 기의 개별기업 } i \text { 의 수익률 } \\
& R_{f, t}: t \text { 기의 무위험이자율 } \\
& \alpha_{i} \text { : 상수항 } \\
& \gamma_{1}, \gamma_{2}, \gamma_{3}, \gamma_{4}, \gamma_{5} \text { : 각 변수별 회귀계수 } \\
& I V O L_{i, t-1}: t-1 \text { 기의 개별기업 } i \text { 의 고유변동성 } \\
& \ln \text { Size }_{i, t-1}: t-1 \text { 기의 개별기업 } i \text { 의 기업규모 } \\
& \ln B / M_{i, t-1}: t-1 \text { 기의 개별기업 } i \text { 의 장부가치 대 시장가치 비율 } \\
& \text { Turn }_{i, t-1}: t-1 \text { 기의 개별기업 } i \text { 의 상장주식거래회전율 } \\
& \operatorname{Max}_{i, t-1}: t-1 \text { 기의 개별기업 } i \text { 의 일별 최고수익률 } \\
& \epsilon_{i, t} \text { : 잔차 }
\end{aligned}
$$

\section{4. 실증분석 결과}

\section{1 고유변동성 포트폴리오 수익률 분석 결과}

<표 3>은 10 분위 고유변동성 포트폴리오의 분석 결과를 보여준다. <표 3>에 따르면 포트폴리오의 수익률을 동일가중수익률로 측정한 경우, 고유변동성이 가장 높은 주식으로 구성된 포트폴리오의 초과수익률에서 고유변동성이 가장 낮은 주식으로 구성된 포트폴리오의 초과 수익률을 차감한 무비용 포트폴리오 High-Low의 초과수익률은 $-0.825 \%$ 로 유의적인 음(-)의 값을 가지는 것으로 나타났다. 이러한 결과는 고유변동성이 낮은 주식의 수익률이 고유변동성이 높은 주식의 수익률보다 상대적으로 높게 나타나는 고유변동성 이상현상을 보고한 선행연구(Ang et al., 2006; Stambaugh et al., 2015)와 일치하는 결과로, 한국 주식시장에 고유변동성 이상현상이 존재한다는 것을 의미한다. Fama-French 3요인 모형의 알파값으로 측정한 위험조정수익률의 경우에도 무비용 포트폴리오 High-Low의 수익률은 $-0.983 \%$ 로 나타나, 음(-)의 프리미엄이 발견된다. 가치가중수익률의 경우, High-Low의 초과수익률은 $-1.625 \%$ 로 나타나고 있고, 위험조정수익률은 $-1.572 \%$ 로 나타나고 있어, 동일가중수익률보다 강한 음(-)의 프리미엄이 발견된다.6)

5) Bali et al.(2011)은 일별 최고수익률과 기대수익률 사이에는 음(-)의 관계가 존재하며, 이러한 잡음 거래자의 복권형 주식 선호 현상이 고유변동성 이상현상을 야기한다고 주장하였다.

6) 고유변동성이 낮은 순서대로 5 개의 포트폴리오를 구성한 5 분위 고유변동성 포트폴리오 분석 결과에서도 마찬가지로, 고유변동성과 수익률 간의 음(-)의 관계가 확인된다. 
The Effects of Investor Sentiment and Limits-to-Arbitrage on the Idiosyncratic Volatility Puzzle

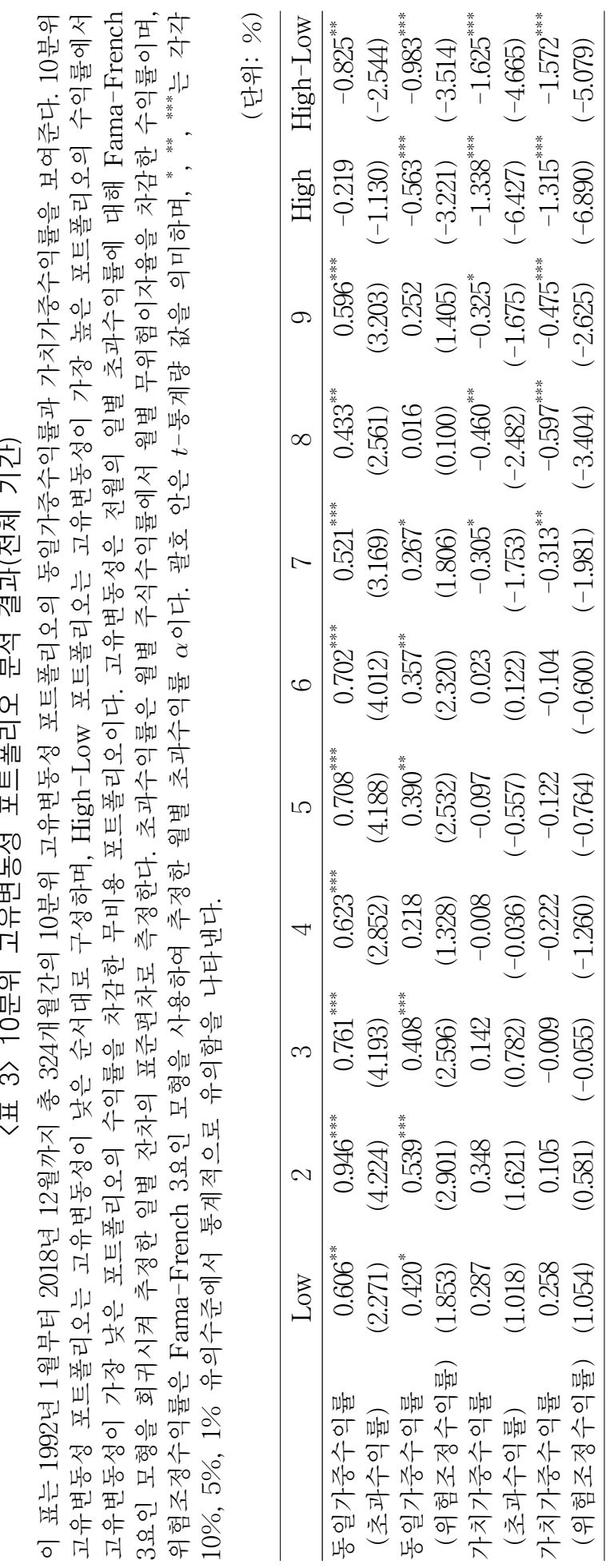


한국증권학회지 제49권 6호 (2020)

이상의 분석 결과를 통해 고유변동성과 수익률이 음(-)의 관계를 가지는 고유변동성 이상현상이 한국 주식시장에 존재한다는 것을 확인하였다. 다음으로, 본 연구는 한국 주식시장에서 고유 변동성 이상현상의 시간에 따른 변화를 분석하기 위해 추가적인 분석을 시행하도록 한다. <그림 $1>$ 은 고유변동성이 높은 포트폴리오의 수익률에서 고유변동성이 낮은 포트폴리오의 수익률을 차감한 무비용 포트폴리오 High-Low의 수익률과 KOSPI 지수의 추이를 보여준다. <그림 $1>$ 을 살펴보면 High-Low의 수익률은 일정하게 음(-)의 프리미엄을 가지지 않고 시간에 따라 변동하고 있음을 알 수 있다. 이는 고유변동성 이상현상이 시간 가변적인 특성을 가지고 있다는 것을 의미한다. 따라서 본 연구는 시간에 따른 고유변동성 이상현상의 변화를 보다 자세히 분석하기 위해, 투자자 심리-고유변동성 포트폴리오와 차익거래 제약-고유변동성 포트폴리오를 구성하여, 투자자 심리와 차익거래 제약의 변동에 따른 고유변동성 이상현상의 변화를 분석하도록 한다.

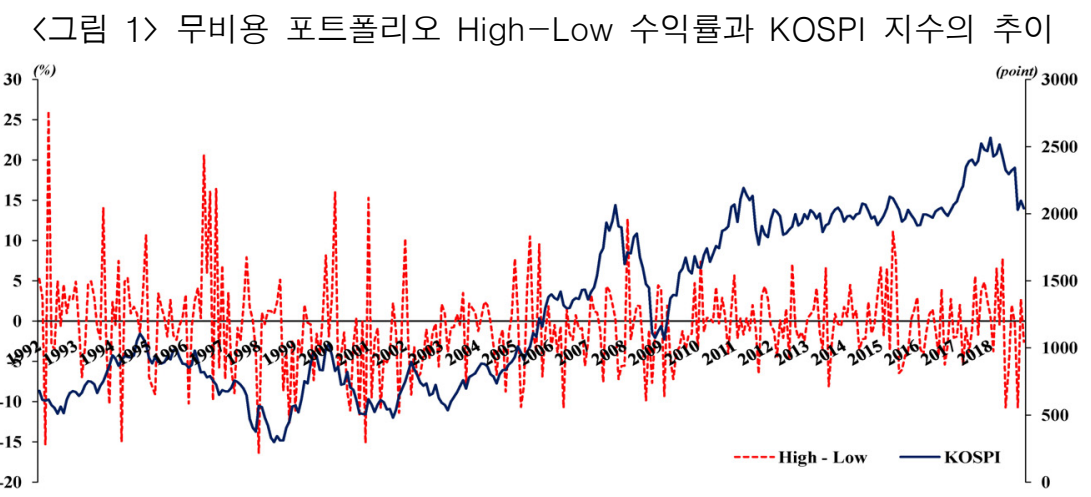

\section{2 투자자 심리-고유변동성 포트폴리오 분석 결과}

<표 4>는 1992년 1월부터 2018년 12월까지 투자자 심리-고유변동성 포트폴리오의 동일가중 초과수익률과 동일가중 위험조정수익률을 보여준다. <표 4>에 따르면 투자자 심리가 낮은 순서로 정렬한 투자자 심리 포트폴리오의 High-Low 월별 초과수익률은 각각 $-2.389 \%,-1.206 \%$, $-1.426 \%$ 로 3 개의 투자자 심리 포트폴리오에서 모두 고유변동성 이상현상이 발견된다. 그러나 투자자 심리에 따른 고유변동성 이상현상의 변화를 알아보기 위해, 투자자 심리가 높은 포트폴리오의 High-Low 수익률과 투자자 심리가 낮은 포트폴리오의 High-Low 수익률의 차이를 분석한 결과 유의미한 차이는 확인되지 않는 것으로 나타났다. 위험조정수익률의 경우에도 투자자 심리 포트폴리오의 High-Low 수익률은 3개 포트폴리오 모두 음(-)의 수익률을 가지는 것으로 나타나므로 고유변동성 이상현상의 존재는 확인할 수 있지만, 투자자 심리의 변동에 따른 고유변동성 이상현상의 유의미한 차이는 관찰되지 않는다.

<표 5>는 투자자 심리-고유변동성 포트폴리오의 가치가중수익률 분석 결과를 보여준다. 동일가중수익률 분석 결과와 마찬가지로, 가치가중수익률 역시 투자자 심리가 낮은 포트폴리오와 투자자 심리가 높은 포트폴리오의 High-Low 수익률은 모두 음(-)의 값을 가지는 것으로 나타났으므로, 고유변동성 이상현상의 존재를 확인할 수 있다. 그러나 투자자 심리가 높은 
The Effects of Investor Sentiment and Limits-to-Arbitrage on the Idiosyncratic Volatility Puzzle

포트폴리오의 High-Low 수익률과 투자자 심리가 낮은 포트폴리오의 High-Low 수익률의 차이는 동일가중수익률의 분석 결과와 동일하게 유의하지 않은 것으로 나타나고 있으므로 투자자 심리의 변화에 따른 고유변동성 이상현상의 심화는 확인되지 않는다.

이상의 투자자 심리-고유변동성 포트폴리오 분석 결과에 따르면, 고유변동성의 음(-)의 프리미엄은 투자자 심리가 높은 포트폴리오와 투자자 심리가 낮은 포트폴리오에서 모두 관찰되므로, 고유변동성 이상현상은 투자자 심리의 강도와 상관없이 발생하고 있다는 것을 알 수 있다. 또한, 투자자 심리에 따른 고유변동성 이상현상의 변화를 살펴보기 위해 투자자 심리가 높은 포트폴리오의 High-Low 수익률과 투자자 심리가 낮은 포트폴리오의 High-Low 수익률의 차이를 분석한 결과 유의하지 않은 것으로 나타났다. 이는 투자자 심리가 고유변동성 이상현상의 심화에 영향을 미치지 않는다는 것을 의미하는 결과이다.

\section{〈표 4〉 투자자 심리-고유변동성 동일가중수익률 포트폴리오 분석 결과}

이 표는 1992년 1월부터 2018년 12월까지 총 324개월간의 투자자 심리-고유변동성 포트폴리오의 월별 동일가중수익률을 보여준다. 투자자 심리 지수는 상대강도지수, 현금흐름지수, 투자심리선, 개인투자자 순매수수량 비율, 투자자예탁금 증가율, 상장주식거래회전율, 신용융자 증가율, 소비자기대지수 증가율, 주식형펀드순자산 증가율, 주식발행비중을 사용하여 주성분분석을 통해 측정하며, 고유변동성은 일별 주식수익률에 대해 Fama-French 3요인 모형을 회귀시켜 나온 잔차의 표준편차로 계산한다. 투자자 심리-고유변동성 포트폴리오는 먼저 투자자 심리 지수가 낮은 순서대로 3개의 포트폴리오를 구성한 다음 각 포트폴리오에 포함된 주식을 고유변동성이 낮은 순서대로 5 개의 포트폴리오로 분류하여 총 15 개의 포트폴리오를 구성한다. 초과수익률은 월별 주식수익률에서 월별 무위험이자율을 차감한 수익률이며, 위험조정수익률은 Fama-French 3요인 모형을 사용하여 추정한 월별 초과수익률 $\alpha$ 이다. 괄호 안은 $t$-통계량 값을 의미하며, ${ }^{*},{ }^{* *},{ }^{* * *}$ 는 각각 $10 \%, 5 \%, 1 \%$ 유의수준에서 통계적으로 유의함을 나타낸다.

\begin{tabular}{|c|c|c|c|c|c|c|}
\hline & Low IVOL & 2 & 3 & 4 & High IVOL & High-Low \\
\hline \multicolumn{7}{|c|}{ 패널 A: 초과수익률 (단위: \%) } \\
\hline Low SENT & $\begin{array}{r}0.372 \\
(1.111)\end{array}$ & $\begin{array}{r}0.393 \\
(1.207)\end{array}$ & $\begin{array}{r}-0.277 \\
(-0.892)\end{array}$ & $\begin{array}{c}-0.673^{*} \\
(-1.798)\end{array}$ & $\begin{array}{c}-2.018^{* * *} \\
(-5.518)\end{array}$ & $\begin{array}{c}-2.389^{* * *} \\
(-4.670)\end{array}$ \\
\hline Medium SENT & $\begin{array}{c}2.537^{* * *} \\
(4.789)\end{array}$ & $\begin{array}{l}1.270^{* * * *} \\
(4.689)\end{array}$ & $\begin{array}{l}1.887^{* * *} \\
(5.758)\end{array}$ & $\begin{array}{c}1.490^{* * *} \\
(4.382)\end{array}$ & $\begin{array}{l}1.331^{* * *} \\
(3.795)\end{array}$ & $\begin{array}{r}-1.206^{*} \\
(-1.868)\end{array}$ \\
\hline High SENT & $\begin{array}{l}1.523^{* * *} \\
(3.131)\end{array}$ & $\begin{array}{l}1.151^{* * *} \\
(3.443)\end{array}$ & $\begin{array}{l}1.600^{* * *} \\
(1.994)\end{array}$ & $\begin{array}{r}-0.028 \\
(-0.085)\end{array}$ & $\begin{array}{r}0.097 \\
(0.258)\end{array}$ & $\begin{array}{c}-1.426^{* *} \\
(-2.306)\end{array}$ \\
\hline High-Low & $\begin{array}{c}1.151^{* *} \\
(1.967) \\
\end{array}$ & $\begin{array}{c}0.758^{*} \\
(1.655)\end{array}$ & $\begin{array}{l}1.877^{* * *} \\
(2.155)\end{array}$ & $\begin{array}{r}0.645 \\
(1.356)\end{array}$ & $\begin{array}{l}2.115^{* * *} \\
(4.124)\end{array}$ & $\begin{array}{r}0.964 \\
(1.239)\end{array}$ \\
\hline \multicolumn{7}{|c|}{ 패널 B: 위험조정수익률 (단위: \%) } \\
\hline Low SENT & $\begin{array}{c}0.880^{* * *} \\
(2.963)\end{array}$ & $\begin{array}{c}0.851^{* * *} \\
(2.671)\end{array}$ & $\begin{array}{r}0.069 \\
(0.217)\end{array}$ & $\begin{array}{r}-0.378 \\
(-1.137)\end{array}$ & $\begin{array}{c}-1.582^{* * *} \\
(-4.643)\end{array}$ & $\begin{array}{l}-2.462^{* * * *} \\
(-5.280)\end{array}$ \\
\hline Medium SENT & $\begin{array}{r}0.707 \\
(1.390)\end{array}$ & $\begin{array}{l}-0.497^{* *} \\
(-2.013)\end{array}$ & $\begin{array}{r}0.111 \\
(0.358)\end{array}$ & $\begin{array}{r}-0.226 \\
(-0.678)\end{array}$ & $\begin{array}{r}-0.490 \\
(-1.445)\end{array}$ & $\begin{array}{c}-1.197^{* *} \\
(-1.961)\end{array}$ \\
\hline High SENT & $\begin{array}{c}0.879^{*} \\
(1.908)\end{array}$ & $\begin{array}{r}0.274 \\
(0.896)\end{array}$ & $\begin{array}{r}0.977 \\
(1.237)\end{array}$ & $\begin{array}{c}-0.535^{*} \\
(-1.701)\end{array}$ & $\begin{array}{r}-0.457 \\
(-1.221)\end{array}$ & $\begin{array}{c}-1.336^{* *} \\
(-2.263)\end{array}$ \\
\hline High-Low & $\begin{array}{r}-0.000 \\
(-0.001)\end{array}$ & $\begin{array}{r}-0.576 \\
(-1.258)\end{array}$ & $\begin{array}{r}0.908 \\
(1.061)\end{array}$ & $\begin{array}{r}-0.156 \\
(-0.343)\end{array}$ & $\begin{array}{c}1.125^{* *} \\
(2.288)\end{array}$ & $\begin{array}{r}1.126 \\
(1.560)\end{array}$ \\
\hline
\end{tabular}


〈표 5〉 투자자 심리-고유변동성 가치가중수익률 포트폴리오 분석 결과

이 표는 1992년 1월부터 2018년 12월까지 총 324개월간의 투자자 심리-고유변동성 포트폴리오의 월별 가치가중수익률을 보여준다. 투자자 심리 지수는 상대강도지수, 현금흐름지수, 투자심리선, 개인투자자 순매수수량 비율, 투자자예탁금 증가율, 상장주식거래회전율, 신용융자 증가율, 소비자기대지수 증가율, 주식형펀드순자산 증가율, 주식발행비중을 사용하여 주성분분석을 통해 측정하며, 고유변동성은 일별 주식수익률에 대해 Fama-French 3요인 모형을 회귀시켜 나온 잔차의 표준편차로 계산한다. 투자자 심리-고유변동성 포트폴리오는 먼저 투자자 심리 지수가 낮은 순서대로 3개의 포트폴리오를 구성한 다음 각 포트폴리오에 포함된 주식을 고유변동성이 낮은 순서대로 5 개의 포트폴리오로 분류하여 총 15 개의 포트폴리오를 구성한다. 초과수익률은 월별 주식수익률에서 월별 무위험이자율을 차감한 수익률이며, 위험조정수익률은 Fama-French 3요인 모형을 사용하여 추정한 월별 초과수익률 $\alpha$ 이다. 괄호 안은 $t$-통계량 값을 의미하며, ${ }^{*},{ }^{* *},{ }^{* * *}$ 는 각각 $10 \%, 5 \%, 1 \%$ 유의수준에서 통계적으로 유의함을 나타낸다.

\begin{tabular}{lcccccc}
\hline & Low IVOL & 2 & 3 & 4 & High IVOL & High-Low \\
\hline 패널 A: 초과수익률 (단위: \%) & & & & \\
\hline Low SENT & 0.313 & 0.215 & -0.451 & $-1.088^{* * *}$ & $-2.630^{* * *}$ & $-2.942^{* * *}$ \\
& $(0.821)$ & $(0.649)$ & $(-1.289)$ & $(-2.795)$ & $(-7.230)$ & $(-5.368)$ \\
Medium SENT & $2.423^{* * *}$ & $0.932^{* * *}$ & $1.632^{* * *}$ & $1.259^{* * *}$ & $0.720^{* *}$ & $-1.704^{* *}$ \\
& $(4.496)$ & $(3.315)$ & $(4.863)$ & $(3.569)$ & $(2.063)$ & $(-2.572)$ \\
High SENT & $1.485^{* * *}$ & $0.710^{* *}$ & 1.068 & -0.329 & -0.594 & $-2.080^{* * * *}$ \\
& $(2.815)$ & $(2.111)$ & $(1.342)$ & $(-1.000)$ & $(-1.523)$ & $(-3.119)$ \\
High-Low & $1.173^{*}$ & 0.494 & $1.519^{*}$ & 0.759 & $2.035^{* * *}$ & 0.863 \\
& $(1.832)$ & $(1.067)$ & $(1.704)$ & $(1.565)$ & $(3.909)$ & $(1.040)$ \\
\hline 패널 B: 위험조정수익률 (단위: \%) & \multicolumn{3}{c}{} & \\
\hline Low SENT & $0.907^{* * *}$ & $0.723^{* *}$ & 0.033 & $-0.652^{*}$ & $-2.066^{* * *}$ & $-2.973^{* * *}$ \\
& $(2.650)$ & $(2.226)$ & $(0.093)$ & $(-1.959)$ & $(-6.089)$ & $(-5.960)$ \\
Medium SENT & 0.710 & $-0.789^{* * *}$ & -0.060 & -0.379 & $-0.984^{* * *}$ & $-1.694^{* * *}$ \\
& $(1.370)$ & $(-2.976)$ & $(-0.185)$ & $(-1.093)$ & $(-2.884)$ & $(-2.699)$ \\
High SENT & $0.945^{*}$ & -0.041 & 0.574 & $-0.724^{* *}$ & $-1.043^{* * *}$ & $-1.988^{* * *}$ \\
& $(1.842)$ & $(-0.135)$ & $(0.732)$ & $(-2.316)$ & $(-2.653)$ & $(-3.038)$ \\
High-Low & 0.038 & $-0.764^{*}$ & 0.541 & -0.072 & $1.023^{* *}$ & 0.985 \\
& $(0.062)$ & $(-1.677)$ & $(0.621)$ & $(-0.157)$ & $(2.002)$ & $(1.237)$ \\
\hline
\end{tabular}

\section{3 차익거래 제약-고유변동성 포트폴리오 분석 결과}

앞선 분석에서 투자자 심리는 고유변동성 이상현상의 심화에 영향을 미치지 않는 것으로 나타났다. 따라서 본 절에서는 차익거래 제약-고유변동성 포트폴리오 분석을 통해 차익거래 제약이 한국 주식시장에서 보고되는 고유변동성 이상현상에 어떠한 영향을 미치는지 분석하도록 한다.

<표 6>은 1992년 1월부터 2018년 12월까지 차익거래 제약-고유변동성 포트폴리오의 동일가중 초과수익률과 동일가중 위험조정수익률을 보여준다. <표 6>에 따르면 차익거래 제약이 낮은 포트폴리오의 경우, 고유변동성이 높은 포트폴리오의 수익률에서 고유변동성이 낮은 포트 폴리오의 수익률을 차감한 무비용 포트폴리오 High-Low의 초과수익률은 $0.199 \%$ 로 양(+)의 
The Effects of Investor Sentiment and Limits-to-Arbitrage on the Idiosyncratic Volatility Puzzle

값을 가지는 것으로 나타났다. 즉, 차익거래 제약이 낮은 포트폴리오에서는 고유변동성 이상현상 대신 고유변동성과 수익률 간의 양 $(+)$ 의 관계가 존재한다. 반면, 차익거래 제약이 높은 포트 폴리오의 경우, High-Low의 초과수익률은 $-1.234 \%$ 로 유의한 음(-)의 값을 가진다. 위험조정 수익률의 경우에도 마찬가지로 차익거래 제약이 낮은 포트폴리오의 High-Low 수익률은 $0.188 \%$ 로 양 $(+)$ 의 값을 가지지만, 차익거래 제약이 높은 포트폴리오의 High-Low 수익률은 $-1.265 \%$ 로 유의한 음(-)의 값을 가진다. 이러한 결과는 고유변동성과 수익률 간의 음(-)의 관계는 차익거래 제약이 높을 때 발생하는 고유변동성의 음(-)의 프리미엄에 기인한다는 것을 의미한다.

차익거래 제약의 변동에 따른 고유변동성 이상현상의 변화를 알아보기 위해 차익거래 제약이 높은 포트폴리오의 High-Low 초과수익률과 차익거래 제약이 낮은 포트폴리오의 High-Low

〈표 6〉 차익거래 제약-고유변동성 동일가중수익률 포트폴리오 분석 결과

이 표는 1992년 1월부터 2018년 12월까지 총 324개월간의 차익거래 제약-고유변동성 포트폴리오의 월별 동일가중수익률을 보여준다. 차익거래 제약 지수는 변동성 지수, TED 스프레드, 신용 스프레드, 호가 스프레드, 비유동성, 주식거래량, 투자의견빈도, 가격제한폭, 공매도 거래, 공매도 잔고를 사용하여 주성분분석을 통해 측정하며, 고유변동성은 일별 주식수익률에 대해 Fama-French 3요인 모형을 회귀시켜 나온 잔차의 표준편차로 계산한다. 차익거래 제약-고유변동성 포트폴리오는 먼저 차익거래 제약 지수가 낮은 순서대로 3 개의 포트폴리오를 구성한 다음 각 포트폴리오에 포함된 주식을 고유변동성이 낮은 순서대로 5 개의 포트폴리오로 분류하여 총 15 개의 포트폴리오를 구성한다. 초과수익률은 월별 주식 수익률에서 월별 무위험이자율을 차감한 수익률이며, 위험조정수익률은 Fama-French 3요인 모형을 사용하여 추정한 월별 초과수익률 $\alpha$ 이다. 괄호 안은 $t$-통계량 값을 의미하며, ${ }^{*},{ }^{* *},{ }^{* * *}$ 는 각각 $10 \%$, $5 \%, 1 \%$ 유의수준에서 통계적으로 유의함을 나타낸다.

\begin{tabular}{|c|c|c|c|c|c|c|}
\hline & Low IVOL & 2 & 3 & 4 & High IVOL & High-Low \\
\hline \multicolumn{7}{|c|}{ 패널 A: 초과수익률 (단위: \%) } \\
\hline Low ACI & $1.123^{* * *}$ & $0.852^{*}$ & $0.975^{* *}$ & $0.884^{*}$ & $1.322^{* *}$ & 0.199 \\
\hline Medium ACI & $\begin{array}{l}(2.596) \\
0.992^{* *}\end{array}$ & $\begin{array}{l}(1.907) \\
1.027^{* *}\end{array}$ & $\begin{array}{l}(2.054) \\
1.098^{* *}\end{array}$ & $\begin{array}{r}(1.885) \\
0.811\end{array}$ & $\begin{array}{r}(2.538) \\
0.705\end{array}$ & $\begin{array}{l}(0.715) \\
-0.287\end{array}$ \\
\hline High ACI & $\begin{array}{l}(2.228) \\
1.011^{* *}\end{array}$ & $\begin{array}{l}(2.121) \\
1.035^{* *}\end{array}$ & $\begin{array}{c}(2.208) \\
1.269^{* *}\end{array}$ & $\begin{array}{r}(1.634) \\
0.684 \\
(1.274)\end{array}$ & $\begin{array}{r}(1.352) \\
-0.223 \\
(-0397)\end{array}$ & $\begin{array}{l}(-0.970) \\
-1.234^{* * *}\end{array}$ \\
\hline High-Low & $\begin{array}{r}(2.052) \\
-0.112 \\
(-0.526)\end{array}$ & $\begin{array}{r}(2.048) \\
0.184 \\
(0.787)\end{array}$ & $\begin{array}{r}(2.223) \\
0.294 \\
(1.005)\end{array}$ & $\begin{array}{r}(1.274) \\
-0.200 \\
(-0.721)\end{array}$ & $\begin{array}{c}(-0.397) \\
-1.545^{* * *} \\
(-4.262)\end{array}$ & $\begin{array}{c}(-3.434) \\
-1.434^{* * *} \\
(-3.610)\end{array}$ \\
\hline \multicolumn{7}{|c|}{ 패널 B: 위험조정수익률 (단위: \%) } \\
\hline Low ACI & $\begin{array}{r}0.530 \\
(1.628)\end{array}$ & $\begin{array}{r}0.253 \\
(0.784)\end{array}$ & $\begin{array}{r}0.389 \\
(1.236)\end{array}$ & $\begin{array}{r}0.285 \\
(0.966)\end{array}$ & $\begin{array}{c}0.718^{* *} \\
(2.258)\end{array}$ & $\begin{array}{r}0.188 \\
(0.675)\end{array}$ \\
\hline Medium ACI & $\begin{array}{r}0.400 \\
(1.283)\end{array}$ & $\begin{array}{r}0.435 \\
(1.438)\end{array}$ & $\begin{array}{c}0.500^{*} \\
(1.698)\end{array}$ & $\begin{array}{r}0.224 \\
(0.738)\end{array}$ & $\begin{array}{r}0.108 \\
(0.348)\end{array}$ & $\begin{array}{r}-0.293 \\
(-0.985)\end{array}$ \\
\hline High ACI & $\begin{array}{r}0.428 \\
(1.460)\end{array}$ & $\begin{array}{r}0.439 \\
(1.486)\end{array}$ & $\begin{array}{c}0.680^{*} \\
(1.892)\end{array}$ & $\begin{array}{r}0.089 \\
(0.271)\end{array}$ & $\begin{array}{c}-0.837^{* *} \\
(-2.188)\end{array}$ & $\begin{array}{l}-1.265^{* * *} \\
(-3.517)\end{array}$ \\
\hline High-Low & $\begin{array}{r}-0.102 \\
(-0.478)\end{array}$ & $\begin{array}{r}0.186 \\
(0.797)\end{array}$ & $\begin{array}{r}0.291 \\
(0.991)\end{array}$ & $\begin{array}{r}-0.196 \\
(-0.702)\end{array}$ & $\begin{array}{c}-1.555^{* * *} \\
(-4.284)\end{array}$ & $\begin{array}{c}-1.453^{* * *} \\
(-3.667)\end{array}$ \\
\hline
\end{tabular}


한국증권학회지 제49권 6호 (2020)

초과수익률을 비교하여 분석한 결과, 두 포트폴리오의 초과수익률 차이는 $-1.434 \%$ 로 $1 \%$ 수준에서 유의한 것으로 나타났다. 위험조정수익률의 경우에도 차익거래 제약이 높을수록 High-Low 수익률은 낮아지는 음(-)의 관계가 동일하게 관찰되며, 차익거래 제약이 높은 포트폴리오의 High-Low 수익률과 차익거래 제약이 낮은 포트폴리오의 High-Low 수익률의 차이는 유의한 음(-)의 값을 가진다. 이러한 결과에 비춰볼 때, 고유변동성 이상현상은 차익거래 제약에 따라 변동하며, 차익거래 제약이 높을 때 고유변동성 이상현상은 심화된다는 것을 알 수 있다.

<표 7>은 가치가중수익률로 계산한 차익거래 제약-고유변동성 포트폴리오 분석 결과를 보여준다. <표 7>에 따르면, 차익거래 제약이 높은 포트폴리오의 High-Low의 초과수익률과 위험조정수익률은 각각 $-1.519 \%$ 와 $-1.534 \%$ 로 음(-)의 값을 가지지만, 차익거래 제약이 낮은

〈표 7〉 차익거래 제약-고유변동성 가치가중수익률 포트폴리오 분석 결과

이 표는 1992년 1월부터 2018년 12월까지 총 324개월간의 차익거래 제약-고유변동성 포트폴리오의 월별 가치가중수익률을 보여준다. 차익거래 제약 지수는 변동성 지수, TED 스프레드, 신용 스프레드, 호가 스프레드, 비유동성, 주식거래량, 투자의견빈도, 가격제한폭, 공매도 거래, 공매도 잔고를 사용하여 주성분분석을 통해 측정하며, 고유변동성은 일별 주식수익률에 대해 Fama-French 3요인 모형을 회귀시켜 나온 잔차의 표준편차로 계산한다. 차익거래 제약-고유변동성 포트폴리오는 먼저 차익거래 제약 지수가 낮은 순서대로 3 개의 포트폴리오를 구성한 다음 각 포트폴리오에 포함된 주식을 고유변동성이 낮은 순서대로 5 개의 포트폴리오로 분류하여 총 15 개의 포트폴리오를 구성한다. 초과수익률은 월별 주식 수익률에서 월별 무위험이자율을 차감한 수익률이며, 위험조정수익률은 Fama-French 3요인 모형을 사용하여 추정한 월별 초과수익률 $\alpha$ 이다. 괄호 안은 $t$-통계량 값을 의미하며, *, **, ***는 각각 $10 \%$, $5 \%, 1 \%$ 유의수준에서 통계적으로 유의함을 나타낸다.

\begin{tabular}{lcrrrrc}
\hline & Low IVOL & \multicolumn{1}{c}{3} & \multicolumn{1}{c}{3} & \multicolumn{1}{c}{ High IVOL } & High-Low \\
\hline 패널 A: 초과수익률 (단위: \%) & & & & & \\
\hline Low ACI & 0.437 & 0.364 & 0.560 & 0.616 & $1.634^{* * *}$ & $1.197^{* *}$ \\
& $(0.883)$ & $(0.711)$ & $(1.165)$ & $(1.125)$ & $(2.739)$ & $(2.499)$ \\
Medium ACI & 0.603 & 0.897 & 0.528 & 0.523 & 0.478 & -0.125 \\
& $(1.248)$ & $(1.559)$ & $(0.996)$ & $(0.928)$ & $(0.758)$ & $(-0.261)$ \\
High ACI & 0.445 & 0.781 & 0.705 & 0.750 & $-1.074^{*}$ & $-1.519^{* * *}$ \\
& $(0.832)$ & $(1.423)$ & $(1.153)$ & $(1.200)$ & $(-1.755)$ & $(-2.906)$ \\
High-Low & 0.008 & 0.417 & 0.145 & 0.134 & $-2.708^{* * *}$ & $-2.716^{* * *}$ \\
& $(0.020)$ & $(0.931)$ & $(0.308)$ & $(0.289)$ & $(-4.870)$ & $(-4.183)$ \\
\hline 패널 B: 위험조정수익률 $($ 단위: $\%)$ & & & & \\
\hline Low ACI & -0.156 & -0.229 & -0.032 & 0.022 & $1.040^{* *}$ & $1.196^{* *}$ \\
& $(-0.305)$ & $(-0.431)$ & $(-0.064)$ & $(0.047)$ & $(2.077)$ & $(2.497)$ \\
Medium ACI & 0.008 & 0.309 & -0.065 & -0.069 & -0.121 & -0.129 \\
High ACI & $(0.018)$ & $(0.682)$ & $(-0.146)$ & $(-0.126)$ & $(-0.242)$ & $(-0.269)$ \\
& -0.145 & 0.189 & 0.112 & 0.158 & $-1.679^{* * *}$ & $-1.534^{* * *}$ \\
High-Low & $(-0.343)$ & $(0.434)$ & $(0.229)$ & $(0.302)$ & $(-3.206)$ & $(-2.932)$ \\
& 0.011 & 0.417 & 0.144 & 0.135 & $-2.719^{* * *}$ & $-2.730^{* * *}$ \\
& $(0.028)$ & $(0.932)$ & $(0.307)$ & $(0.292)$ & $(-4.879)$ & $(-4.200)$ \\
\hline
\end{tabular}


The Effects of Investor Sentiment and Limits-to-Arbitrage on the Idiosyncratic Volatility Puzzle

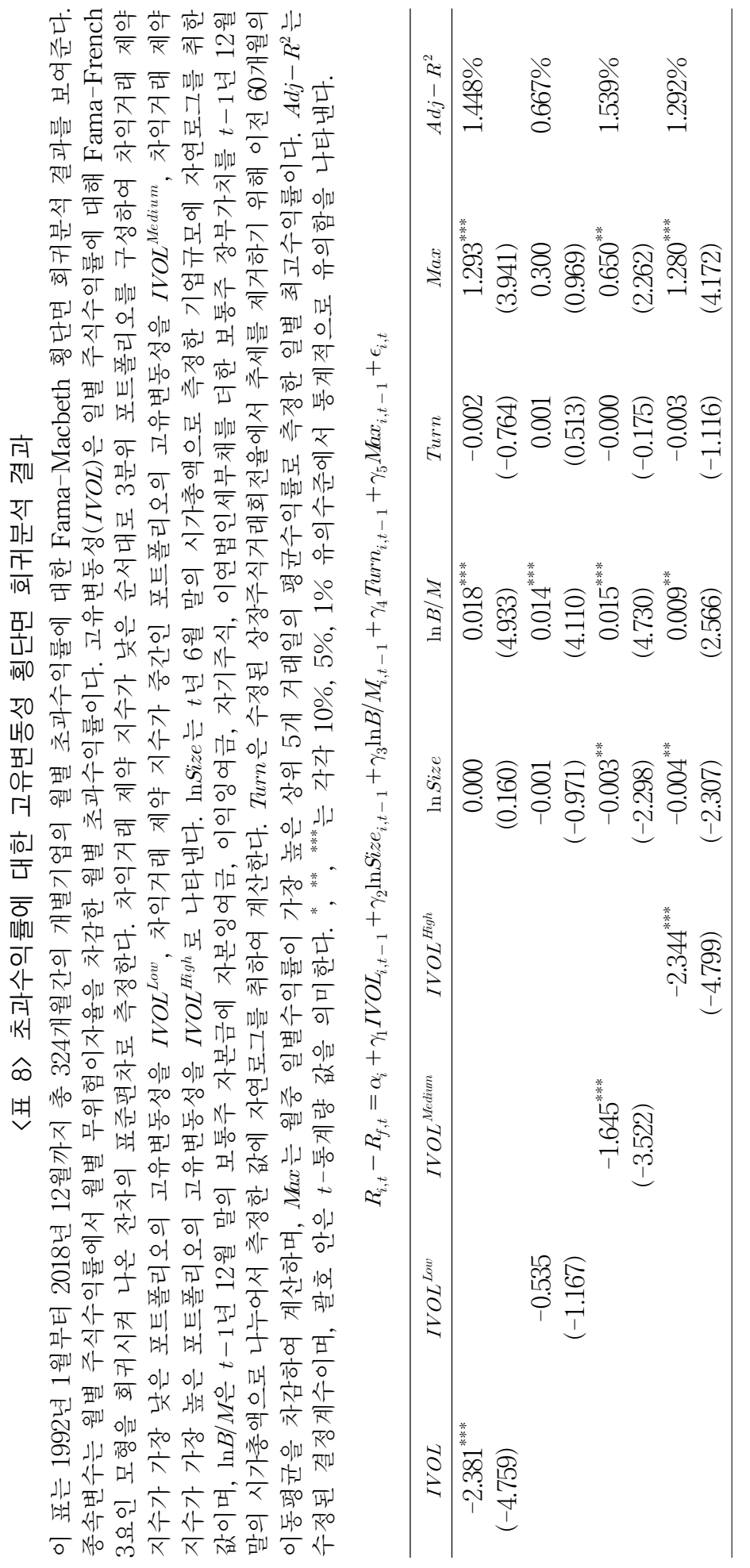


한국증권학회지 제49권 6호 (2020)

포트폴리오의 High-Low의 초과수익률과 위험조정수익률은 $1.197 \%$ 와 $1.196 \%$ 로 양(+)의 값을 가진다. 따라서 동일가중수익률과 마찬가지로 고유변동성 이상현상은 차익거래 제약이 높을 때 발생하는 고유변동성의 음(-)의 프리미엄에 기인한다는 사실을 확인할 수 있다. 가치가중 수익률의 경우에도 고유변동성의 음(-)의 프리미엄은 차익거래 제약이 높을수록 강해지며, 차익거래 제약이 높은 포트폴리오와 차익거래 제약이 낮은 포트폴리오의 고유변동성 프리미엄 차이는 초과수익률의 경우 $-2.716 \%$, 위험조정수익률의 경우 $-2.730 \%$ 로 모두 $1 \%$ 수준에서 유의한 음 $(-)$ 의 값을 가진다.

또한, 본 연구에서는 차익거래 제약이 고유변동성 이상현상에 미치는 영향을 검증하기 위해 1992년 1월부터 2018년 12월까지 개별기업의 월별 초과수익률에 대한 고유변동성 횡단면 회귀분석을 시행하였다. <표 8>에 따르면 고유변동성은 기업규모, 장부가치 대 시장가치 비율, 상장주식거래회전율, 일별 최고수익률을 통제한 후에도 수익률과 유의한 음(-)의 관계를 가지는 것으로 나타났다. 이러한 고유변동성의 음(-)의 프리미엄에 차익거래 제약이 미치는 영향을 분석하기 위하여, 차익거래 제약 지수가 낮은 순서대로 3 개의 포트폴리오를 구성하여, 각 포트폴리오의 고유변동성과 수익률 간의 관계를 분석하였다. 분석 결과, 차익거래 제약 지수가 가장 높은 포트폴리오와 중간인 포트폴리오의 고유변동성은 $1 \%$ 수준에서 수익률과 유의한 음(-)의 관계를 가지는 것으로 나타난 반면, 차익거래 제약 지수가 가장 낮은 포트폴리오의 고유변동성은 수익률에 대해 유의미한 영향을 미치지 못하는 것으로 나타났다. 이는 고유변동성의 음(-)의 프리미엄은 차익거래 제약이 높은 포트폴리오의 고유변동성과 수익률 간의 음(-)의 관계에서 기인한다는 주장을 뒷받침하는 결과라고 할 수 있다.

이상의 분석 결과를 종합하여 볼 때, 한국 주식시장에 존재하는 고유변동성 이상현상은 차익거래 제약이 높은 포트폴리오에서 나타나는 고유변동성의 음(-)의 프리미엄에 기인한다. 즉, 차익거래 제약이 강해질수록 과대평가된 주식의 매도가 과소평가된 주식의 매수에 비해 상대적으로 어려워지는 차익거래 비대칭현상으로 인해 고유변동성 이상현상이 발생한다. 또한, 차익거래 제약이 강해질수록 고유변동성의 음(-)의 프리미엄이 커지는 것으로 나타났으며, 이는 차익거래 제약이 증가하여 차익거래가 어려워지는 기간에 고유변동성 이상현상이 더욱 심화된다는 것을 의미한다.

\section{4 공매도 제약에 따른 고유변동성 이상현상}

차익거래 제약-고유변동성 포트폴리오 분석 결과에 따르면 고유변동성 이상현상은 차익거래 제약이 높은 기간에 심화되는 것으로 나타났다. 따라서 본 절에서는 한국 주식시장에서 공매도 거래가 금지되어 차익거래 제약이 높아진 기간의 고유변동성 이상현상과 공매도 거래가 허용되어 상대적으로 차익거래 제약이 낮은 기간의 고유변동성 이상현상을 비교하여 분석한다.

<표 9>와 <표 10>은 각각 한국 주식시장에서 공매도 거래가 금지된 기간7)과 공매도 거래가 허용된 기간의 10 분위 고유변동성 포트폴리오 분석 결과를 보여준다. <표 $9>$ 와 <표 $10>$ 의

7) 한국 주식시장은 2008년 10월부터 2009년 5월까지, 그리고 2011년 8월부터 2011년 10월까지 두 차례에 걸쳐 총 11 개월 동안 공매도 거래를 한시적으로 금지하였다. 
The Effects of Investor Sentiment and Limits-to-Arbitrage on the Idiosyncratic Volatility Puzzle

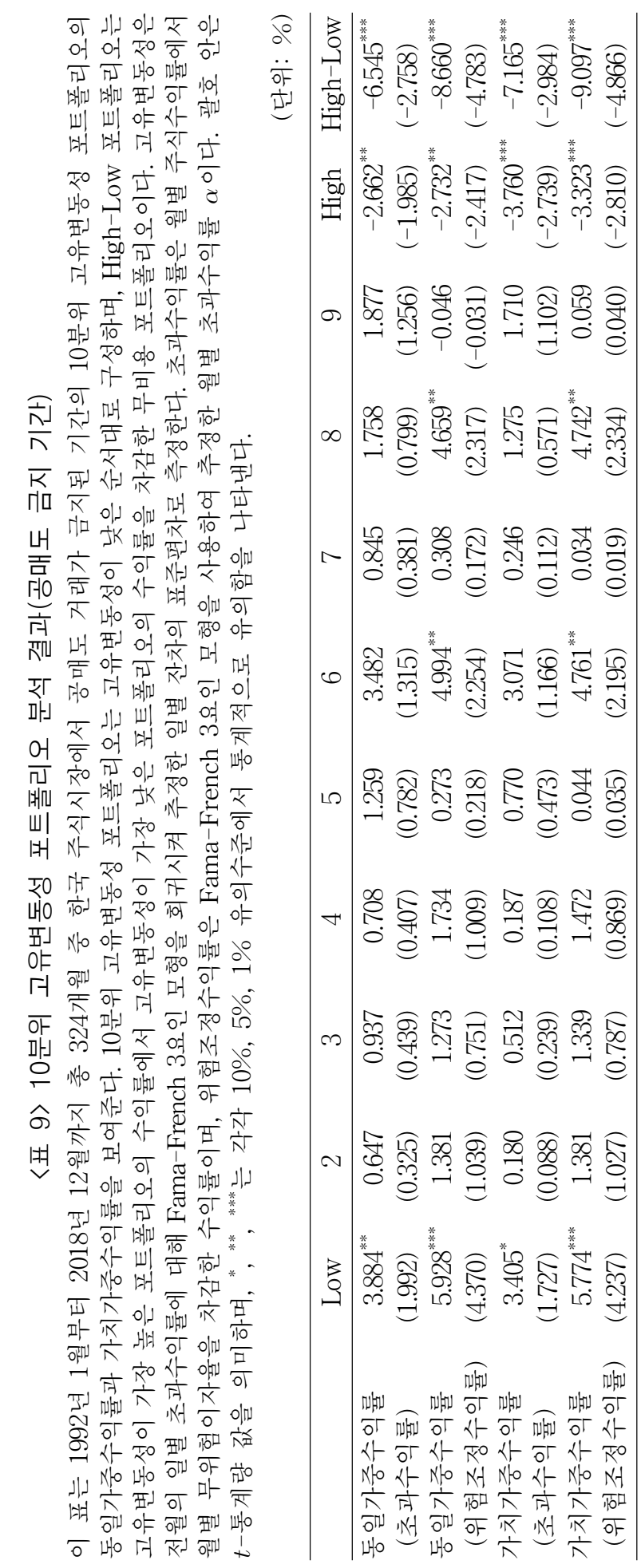




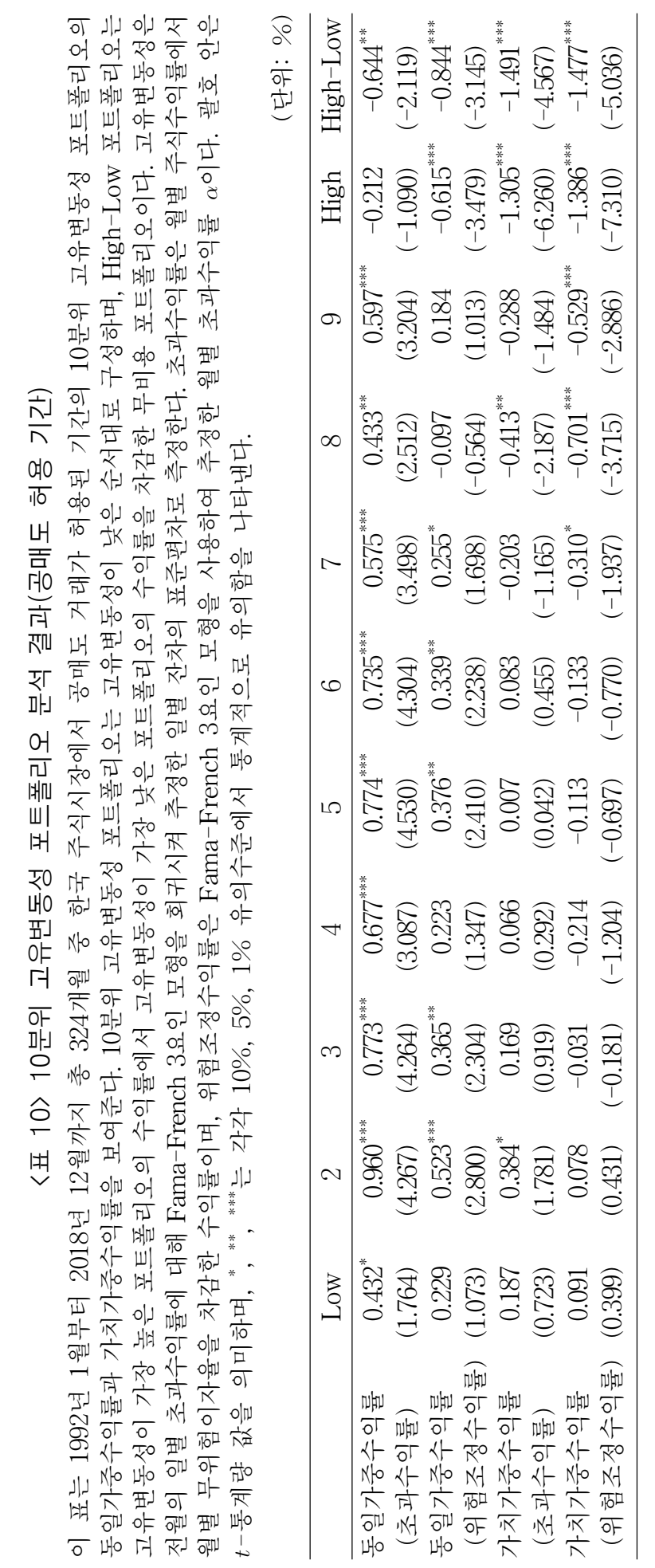


The Effects of Investor Sentiment and Limits-to-Arbitrage on the Idiosyncratic Volatility Puzzle

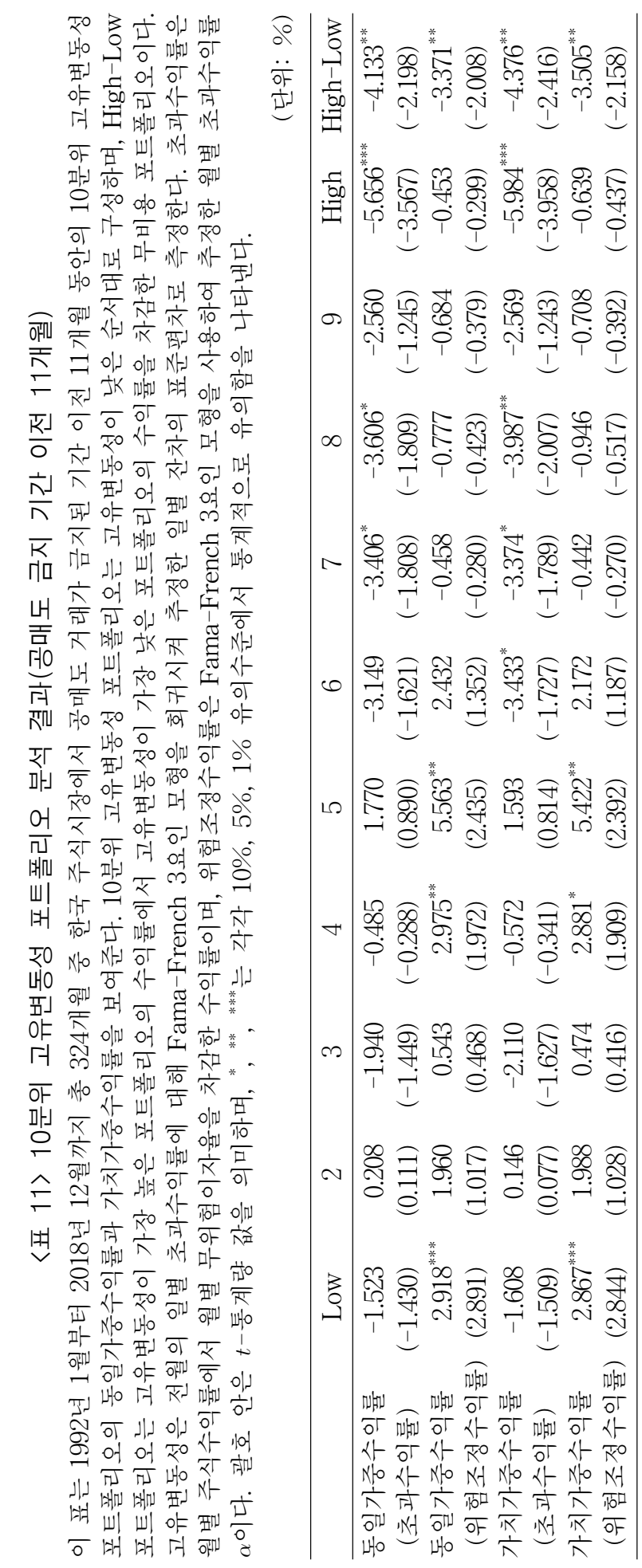




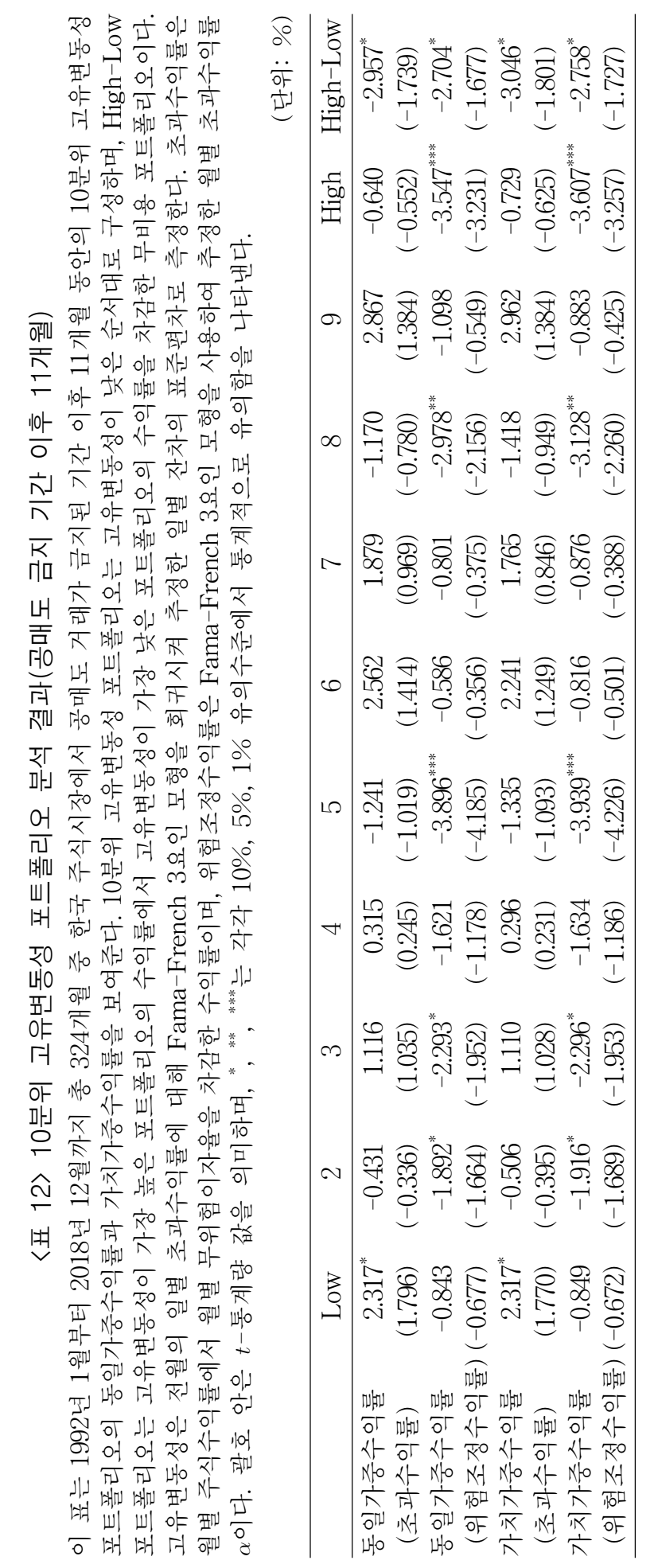


The Effects of Investor Sentiment and Limits-to-Arbitrage on the Idiosyncratic Volatility Puzzle

결과를 비교하여 살펴보면, 동일가중수익률로 계산하였을 때, 공매도 거래가 금지된 기간 동안 무비용 포트폴리오 High-Low의 초과수익률은 $-6.545 \%$, 위험조정수익률은 $-8.660 \%$ 로 나타나고 있는 반면, 공매도 거래가 허용된 기간 동안 High-Low의 수익률은 $-0.644 \%$ 의 초과수익률과 $-0.844 \%$ 의 위험조정수익률을 가지는 것으로 나타난다. 공매도 거래가 금지된 기간 동안의 High-Low의 음(-)의 프리미엄이 공매도 거래가 허용된 기간에 비해 초과수익률의 경우 $5.901 \%$, 위험조정수익률의 경우 $7.816 \%$ 만큼 크게 나타나고 있으므로, 이는 공매도 거래가 금지되었을 때 고유변동성 이상현상이 보다 심화된다는 것을 의미한다. 가치가중수익률로 계산하였을 때도 마찬가지로, 공매도 거래가 금지된 기간의 High-Low의 수익률과 공매도 거래가 허용된 기간의 High-Low의 수익률은 모두 음(-)의 값을 가지지만, 공매도 거래가 금지된 기간의 High-Low의 음(-)의 프리미엄은 공매도 거래가 허용된 기간의 High-Low의 음(-)의 프리미엄에 비해 초과수익률의 경우 5.674\%, 위험조정수익률의 경우 $7.620 \%$ 만큼 크게 나타난다. 이러한 결과는 5 분위 고유변동성 포트폴리오 분석 결과에서도 동일하게 나타난다.

본 연구의 분석 대상 기간인 1992년 1월부터 2018년 12월까지 324개월 중 공매도 거래가 허용된 기간은 313 개월인 반면, 공매도 거래가 금지된 기간은 11 개월로 관측 기간의 차이가 존재한다. 따라서 관측 기간을 동일하게 하기 위해 공매도 거래가 금지된 2008년 10월 이전 11 개월과 공매도 거래 금지가 끝난 2009년 5월 이후 11 개월에 대한 고유변동성 포트폴리오 분석을 시행하였다. <표 11>은 공매도 거래가 금지되기 전인 2007년 11월부터 2008년 9월까지 11 개월 동안의 10 분위 고유변동성 포트폴리오 분석 결과를 보여주며, <표 $12>$ 는 공매도 거래 금지가 끝난 후인 2009년 6월부터 2010년 4월까지 11개월 동안의 10분위 고유변동성 포트폴리오 분석 결과를 보여준다. 분석 결과에 따르면, 공매도 거래가 금지된 기간 전·후 11 개월의 무비용 포트폴리오 High-Low의 음(-)의 프리미엄은 공매도 거래가 금지된 기간에 비해 작은 것으로 나타났다. 따라서 공매도가 금지된 기간은 공매도가 허용된 기간에 비해 고유변동성이 높은 포트폴리오의 수익률은 더욱 낮아지고, 고유변동성이 낮은 포트폴리오의 수익률은 더욱 높아져서 결과적으로 무비용 포트폴리오 High-Low의 음(-)의 프리미엄이 심화된다는 것을 알 수 있다.

공매도 거래 제약에 따른 고유변동성 포트폴리오 분석 결과를 종합하여 볼 때, 한국 주식시장 에서 고유변동성 이상현상은 공매도 거래가 금지된 기간에 보다 강해진다는 것을 알 수 있다. 이러한 결과는 한국 주식시장에서 투자자를 보호하기 위해 시행되는 공매도의 제약이 오히려 시장의 이상현상을 심화시킴으로써 본연의 목적과 상반된 결과를 초래할 수 있다는 것을 의미한다.

\section{5 . 결론}

Ang et al.(2006)에서 밝혀낸 고유변동성 이상현상은 전통적 재무이론의 근간을 이루는 위험-수익 상충관계로 설명되지 않는 퍼즐로 학계에 큰 반향을 일으켰다. 고유변동성 이상현상에 대한 연구는 고유변동성 이상현상이 실제로 위험-수익 상충관계로 설명되지 않는 현상이 맞는지 검증하는 연구로부터 시작해서, 행동재무론의 관점에서 고유변동성 이상현상을 설명하려는 연구로 이어져 오고 있다. 행동재무론을 통해 고유변동성 이상현상을 설명하는 연구들은 잡음 
한국증권학회지 제49권 6호 (2020)

거래자들의 투자자 심리에 의한 거래행태를 원인으로 지적한다. 인지적 편향의 영향으로 잡음 거래자들은 복권형 주식을 선호하는 거래행태를 보이게 되고, 확률이 낮은 고수익을 추구함과 동시에 고위험에 대한 낮은 보상을 감수하는 잡음 거래자의 투자자 심리가 고유변동성 이상현상을 유발한다고 설명한다. 이러한 관점에서 분석한 연구들은 높은 왜도와 높은 일별 최고수익률과 같은 복권형 주식의 특성을 사용하여 수익률과의 음 $(-)$ 의 관계가 존재함을 밝혀냈다. 행동재무론의 관점에서 고유변동성 이상현상을 설명하려는 또 다른 연구 흐름은 차익거래 제약을 통한 고유변동성 이상현상의 설명이다. 잡음 거래자의 거래행태로 발생한 차익거래의 기회가 시장에 존재함에도 불구하고, 공매도 제약과 같은 차익거래의 제약으로 인해 차익거래 비대칭 현상이 나타나게 되고, 이로 인해 고유변동성 이상현상이 발생한다는 것이다. Stambaugh et al.(2015) 등의 연구는 과대평가된 주식과 과소평가된 주식을 분류하여 포트폴리오를 구성함으로써 이를 증명하였다. 과소평가된 주식의 고유변동성은 수익률과 양 $(+)$ 의 관계를 가지는 반면, 과대평가된 주식의 고유변동성은 수익률과 음(-)의 관계를 가지는 것으로 나타나, 고유변동성 이상현상은 과대평가된 주식의 차익거래가 제약으로 인해 원활히 이루어지지 않는 데 기인한다는 것을 밝혀냈다. 고유변동성 이상현상에 대한 국내연구는 이러한 연구 흐름에 맞춰 잡음 거래자의 거래행태와 차익거래 제약을 통해 고유변동성 이상현상을 야기하는 원인을 밝히는데 집중되고 있다. 본 연구는 고유변동성 이상현상의 원인이 되는 특정 주식집단을 분석하는 것에서 더 나아가 투자자 심리와 차익거래 제약에 따라 고유변동성 이상현상이 심화되는 현상을 밝혀내고자 하였다.

본 연구는 1992년 1월부터 2018년 12월까지 총 324개월간 한국 유가증권시장을 대상으로 투자자 심리와 차익거래 제약이 고유변동성 이상현상에 미치는 영향에 대해 분석하였다. 먼저, 선행연구에서 투자자 심리를 나타낸다고 보고된 상대강도지수, 현금흐름지수, 투자심리선, 개인투자자 순매수수량 비율, 투자자예탁금 증가율, 상장주식거래회전율, 신용융자 증가율, 소비자기대지수 증가율, 주식형펀드순자산 증가율, 주식발행비중을 사용하여 주성분분석을 통해 투자자 심리 지수를 구성하였다. 또한, 기존의 선행연구에서 차익거래 제약을 나타내는 변수로 보고된 변동성 지수, TED 스프레드, 신용 스프레드, 호가 스프레드, 비유동성, 주식거래량, 투자의견빈도와 함께 한국 주식시장의 특성을 반영하는 변수인, 가격제한폭과 공매도 거래, 공매도 잔고를 사용하여 차익거래 제약 지수를 구성하여 고유변동성 이상현상에 미치는 영향을 분석하였다. 투자자 심리 지수와 차익거래 제약 지수에 포함되어있는 거시경제변수의 영향을 제거하기 위해 이전 60 개월 동안 회귀계수를 추정하여 1 개월씩 순차시켜서 측정한 잔차를 투자자 심리 지수와 차익거래 제약 지수로 사용하였다.

거시경제변수의 영향을 통제한 투자자 심리와 차익거래 제약이 고유변동성 이상현상에 미치는 영향을 분석하기 위해, 먼저 Fama-French 3요인 모형을 사용하여 측정한 일별 잔차의 표준편차로 고유변동성을 측정하였고, 측정한 고유변동성을 사용하여 고유변동성 포트폴리오를 구성하여 한국 주식시장에서 고유변동성 이상현상의 존재를 확인하고자 하였다. 분석 결과, 고유변동성이 낮은 주식의 수익률이 고유변동성이 높은 주식의 수익률보다 높게 나타나는 음(-)의 관계가 발견되었고, 고유변동성 이상현상의 존재를 확인할 수 있었다. 다음으로, 투자자 심리와 차익거래 
The Effects of Investor Sentiment and Limits-to-Arbitrage on the Idiosyncratic Volatility Puzzle

제약이 고유변동성 이상현상에 미치는 영향을 분석하기 위해 투자자 심리-고유변동성 포트 폴리오와 차익거래 제약-고유변동성 포트폴리오를 구성하여 포트폴리오 분석을 시행하였다. 포트폴리오 분석 결과, 투자자 심리가 높은 포트폴리오와 투자자 심리가 낮은 포트폴리오에서 모두 고유변동성의 음(-)의 프리미엄이 관찰되었지만, 투자자 심리가 변화하는 데 따른 고유변동성 이상현상의 심화는 확인되지 않았다. 반면, 차익거래 제약-고유변동성 포트폴리오 분석 결과에 따르면, 차익거래 제약이 낮은 주식으로 구성된 포트폴리오에서는 고유변동성과 수익률의 음(-)의 관계를 확인할 수 없었지만, 차익거래 제약이 높은 주식으로 구성된 포트폴리오 에서는 고유변동성과 수익률 사이에 존재하는 강한 음 $(-)$ 의 프리미엄을 확인할 수 있었다. 이러한 결과는 고유변동성 이상현상은 차익거래 제약이 강한 주식에 기인한다는 선행연구의 주장을 지지하는 결과이다. 또한, 차익거래 제약이 강할수록 고유변동성과 수익률의 음 $(-)$ 의 관계 역시 강해지는 것으로 나타났고, 이러한 결과를 통해 차익거래 제약이 강해져서 차익거래가 어려워지는 기간에 고유변동성 이상현상이 더욱 심화된다는 결론을 얻을 수 있었다. 보다 강건한 검증을 위해 시행한 횡단면 회귀분석 결과에서도 차익거래 제약이 낮은 포트폴리오의 고유변동성은 수익률에 유의미한 영향을 주지 못하는 것으로 나타난 반면, 차익거래 제약이 높은 포트폴리오의 고유변동성은 수익률과 유의한 음(-)의 관계를 가지는 것으로 나타났다. 마지막으로 한국 주식시장에서 공매도 거래가 금지되어 차익거래 제약이 높았던 기간의 고유변동성 이상현상과 공매도 거래가 허용되어 차익거래 제약이 상대적으로 낮았던 기간의 고유변동성 이상현상을 비교하여 분석하였다. 분석 결과, 고유변동성 이상현상은 공매도 거래가 허용된 기간에 비해 공매도 거래가 금지된 기간 동안 더욱 강해지는 것으로 나타났다.

본 연구가 가지는 의의는 다음과 같다. 첫째, 기존의 연구들에서 보고된 변수들을 종합하여 단일지수를 구성하여 분석함으로써, 투자자 심리와 차익거래 제약이 한국 주식시장에 미치는 영향에 대해 보다 의미 있는 결과를 제시하였다. 둘째, 투자자 심리와 차익거래 제약에 영향을 미치는 거시경제변수를 통제한 지수를 구성함으로써, 보다 정확한 투자자 심리와 차익거래 제약의 영향을 확인하였다. 셋째, 고유변동성 이상현상을 야기하는 원인을 설명하는 것에서 더 나아가 투자자 심리와 차익거래 제약이 고유변동성 이상현상에 미치는 영향을 비교하여 분석하고, 차익거래 제약이 증가하여 차익거래가 어려워진 기간 동안 고유변동성 이상현상이 더욱 심화된다는 것을 밝혀냄으로써 한국 주식시장의 고유변동성 이상현상을 연구하는 데 있어서 의미 있는 실증 결과를 제시하였다. 넷째, 한국 주식시장의 특성을 반영하는 가격제한폭과 공매도 거래 변수를 사용함으로써, 한국 주식시장에 존재하는 고유변동성 이상현상의 특성을 정확히 포착하여 분석하였다. 나아가 본 연구는 이러한 분석을 통해 현재 한국 주식시장에서 투자자를 보호하기 위해 시행되고 있는 제도들이 실제 투자자들에게 미치는 결과를 도출함으로써, 한국 주식시장과 유관기관들이 나아가야할 방향을 제시하는데 이론적 근거를 제공할 수 있을 것으로 기대된다. 


\section{References}

Amihud, Y., 2002, Illiquidity and Stock Returns: Cross-section and Time-series Effects, Journal of Financial Markets, Vol. 5 (1), pp. 31-56.

Ang, A., R. J. Hodrick, Y. Xing, and X. Zhang, 2006, The Cross-Section of Volatility and Expected Returns, Journal of Finance, Vol. 61 (1), pp. 259-299.

Ang, A., R. J. Hodrick, Y. Xing, and X. Zhang, 2009, High Idiosyncratic Volatility and Low Returns: International and Further U.S. Evidence, Journal of Financial Economics, Vol. 91 (1), pp. 1-23.

Ang, A., S. Gorovyy, and G. B. van Inwegen, 2011, Hedge Fund Leverage, Journal of Financial Economics, Vol. 102 (1), pp. 102-126.

Baker, M., and J. C. Stein, 2004, Market Liquidity as a Sentiment Indicator, Journal of Financial Markets, Vol. 7 (3), pp. 271-299.

Baker, M., and J. Wurgler, 2000, The Equity Share in New Issues and Aggregate Stock Returns, Journal of Finance, Vol. 55 (5), pp. 2219-2257.

Baker, M., and J. Wurgler, 2006, Investor Sentiment and the Stock Market, Journal of Finance, Vol. 61 (4), pp. 1645-1680.

Bali, T. G., and N. Cakici, 2008, Idiosyncratic Volatility and the Cross Section of Expected Returns, Journal of Financial and Quantitative Analysis, Vol. 43 (1), pp. 29-58.

Bali, T. G., N. Cakici, and R. F. Whitelaw, 2011, Maxing Out: Stocks as Lotteries and the Cross-Section of Expected Returns, Journal of Financial Economics, Vol. 99 (2), pp. 427-446.

Brown, G. W., and M. T. Cliff, 2004, Investor Sentiment and the Near-term Stock Market, Journal of Empirical Finance, Vol. 11 (1), pp. 1-27.

Chan, S. H., K. A. Kim, and S. G. Rhee, 2005, Price Limit Performance: Evidence from Transactions Data and the Limit Order Book, Journal of Empirical Finance, Vol. 12 (2), pp. 269-290.

Chen, H., T. T. Chong, and X. Duan, 2010, A Principal-component Approach to Measuring Investor Sentiment, Quantitative Finance, Vol. 10 (4), pp. 339-347.

Chordia, T., R. Roll, and A. Subrahmanyam, 2008, Liquidity and Market Efficiency, Journal of Financial Economics, Vol. 87 (2), pp. 249-268.

Corwin, S. A., and P. Schultz, 2012, A Simple Way to Estimate Bid-Ask Spreads from Daily High and Low Prices, Journal of Finance, Vol. 67 (2), pp. 719-760.

Diamond, D. W., and R. E. Verrecchia, 1987, Constraints on Short-Selling and Asset Price Adjustment to Private Information, Journal of Financial Economics, Vol. 18 (2), pp. 277-311.

Eom, C., 2018, Cross-Sectional Mispricing and Idiosyncratic Volatility: A New Approach, Korean Journal of Financial Studies, Vol. 47 (3), pp. 471-503. 
The Effects of Investor Sentiment and Limits-to-Arbitrage on the Idiosyncratic Volatility Puzzle

Eom, C., W. B. Lee, R. S. Park, U. Chang, and J. W. Park, 2014, A Study on the Relationship between Idiosyncratic Volatility and Stock Returns in the Korean Stock Markets, Korean Journal of Financial Studies, Vol. 43 (4), pp. 753-784.

Fama, E. F., and J. D. MacBeth, 1973, Risk, Return, and Equilibrium: Empirical Tests, Journal of Political Economy, Vol. 81 (3), pp. 607-636.

Fama, E. F., and K. R. French, 1993, Common Risk Factors in the Returns on Stocks and Bonds, Journal of Financial Economics, Vol. 33 (1), pp. 3-56.

Fink, J. D., K. E. Fink, and H. He, 2012, Expected Idiosyncratic Volatility Measures and Expected Returns, Financial Management, Vol. 41 (3), pp. 519-553.

Fisher, K. L., and M. Statman, 2003, Consumer Confidence and Stock Returns, Journal of Portfolio Management, Vol. 30 (1), pp. 115-127.

Frazzini, A., and O. A. Lamont, 2008, Dumb Money: Mutual Fund Flows and the Cross-Section of Stock Returns, Journal of Financial Economics, Vol. 88 (2), pp. 299-322.

Fu, F., 2009, Idiosyncratic Risk and the Cross-Section of Expected Stock Returns, Journal of Financial Economics, Vol. 91 (1), pp. 24-37.

Goyal, A., and P. Santa-Clara, 2003, Idiosyncratic Risk Matters!, Journal of Finance, Vol. 58 (3), pp. 975-1007.

Gromb, D., and D. Vayanos, 2002, Equilibrium and Welfare in Markets with Financially Constrained Arbitrageurs, Journal of Financial Economics, Vol. 66 (2), pp. 361-407.

Gu, M., W. Kang, and B. Xu, 2018, Limits of Arbitrage and Idiosyncratic Volatility: Evidence from China Stock Market, Journal of Banking and Finance, Vol. 86 (1), pp. 240-258.

Hong, H., T. Lim, and J. C. Stein, 2000, Bad News Travels Slowly: Size, Analyst Coverage, and the Profitability of Momentum Strategies, Journal of Finance, Vol. 55 (1), pp. 265-295.

Jacobs, H., 2015, What Explains the Dynamics of 100 Anomalies?, Journal of Banking and Finance, Vol. 57 (1), pp. 65-85.

Kho, B. C., and J. W. Kim, 2014, Low Volatility Anomaly and Its Profitability in Korean Stock Markets, Korean Journal of Financial Studies, Vol. 43 (3), pp. 573-603.

Kim, D., and H. Na, 2018, Investor Sentiment, Anomalies, and Macroeconomic Conditions, Asia-Pacific Journal of Financial Studies, Vol. 47 (6), pp. 751-804.

Kim, K. A., and S. G. Rhee, 1997, Price Limits Performance: Evidence from the Tokyo Stock Exchange, Journal of Finance, Vol. 52 (2), pp. 885-901.

Kim, K., and J. Byun, 2010, Effect of Investor Sentiment on Market Response to Stock Split Announcement, Asia-Pacific Journal of Financial Studies, Vol. 39 (6), pp. 687-719.

Kim, O., and R. E. Verrecchia, 1994, Market Liquidity and Volume Around Earnings Announcements, Journal of Accounting and Economics, Vol. 17 (1), pp. 41-67.

Kim, T., and Y. Byun, 2011, The Relationship between Idiosyncratic Volatility and Expected Returns in the Korea Stock Markets, Korean Journal of Financial Studies, Vol. 40 (3), pp. 525-550. 
한국증권학회지 제49권 6호 (2020)

Kumar, A., 2009, Who Gambles in the Stock Market?, Journal of Finance, Vol. 64 (4), pp. 1889-1933.

Kumar, A., and C. M. C. Lee, 2006, Retail Investor Sentiment and Return Comovements, Journal of Finance, Vol. 61 (5), pp. 2451-2486.

Lee, S. B., and J. H. Seo, 2007, Study on the Dynamic Relationship between the Excess Returns of the Stock Market and Idiosyncratic Volatility and the Information Efficiency, Korean Journal of Financial Studies, Vol. 36 (3), pp. 387-423.

Lou, X., and T. Shu, 2017, Price Impact or Trading Volume: Why is the Amihud (2002) Measure Priced?, Review of Financial Studies, Vol. 30 (12), pp. 4481-4520.

Mashruwala, C., S. Rajgopal, and T. Shevlin, 2006, Why Is the Accrual Anomaly Not Arbitraged Away? The Role of Idiosyncratic Risk and Transaction Costs, Journal of Accounting and Economics, Vol. 42 (1), pp. 3-33.

Merton, R. C., 1987, A Simple Model of Capital Market Equilibrium with Incomplete Information, Journal of Finance, Vol. 42 (3), pp. 483-510.

Mitton, T., and K. Vorkink, 2007, Equilibrium Underdiversification and the Preference for Skewness, Review of Financial Studies, Vol. 20 (4), pp. 1255-1288.

Nam, S. K., and J. H. Park, 1996, Is the Credit Balance in Margin Account a Predictor of the Stock Price Index?, Korean Journal of Financial Studies, Vol. 19 (1), pp. 27-51.

Odean, T., 1998, Are Investors Reluctant to Realize Their Losses?, Journal of Finance, Vol. 53 (5), pp. 1775-1798.

Odean, T., 1999, Do Investors Trade Too Much?, American Economic Review, Vol. 89 (5), pp. 1279-1298.

Sadka, R., and A. Scherbina, 2007, Analyst Disagreement, Mispricing, and Liquidity, Journal of Finance, Vol. 62 (5), pp. 2367-2403.

Saffi, P. A. C., and K. Sigurdsson, 2011, Price Efficiency and Short Selling, Review of Financial Studies, Vol. 24 (3), pp. 821-852.

Shleifer, A., and R. W. Vishny, 1997, The Limits of Arbitrage, Journal of Finance, Vol. 52 (1), pp. 35-55.

Sim, M., 2016, Higher Moments and the Cross-Section of Stock Returns, Korean Journal of Financial Management, Vol. 33 (1), pp. 71-102.

Stambaugh, R. F., J. Yu, and Y. Yuan, 2015, Arbitrage Asymmetry and the Idiosyncratic Volatility Puzzle, Journal of Finance, Vol. 70 (5), pp. 1903-1948.

Yang, C., and B. Gao, 2014, The Term Structure of Sentiment Effect in Stock Index Futures Market, North American Journal of Economics and Finance, Vol. 30 (1), pp. 171-182.

Yang, C., and R. Zhang, 2014, Does Mixed-Frequency Investor Sentiment Impact Stock Returns? Based on the Empirical Study of MIDAS Regression Model, Applied Economics, Vol. 46 (9), pp. 966-972. 
The Effects of Investor Sentiment and Limits-to-Arbitrage on the Idiosyncratic Volatility Puzzle

\section{〈부록 1〉투자자 심리 변수 측정}

$$
\begin{aligned}
& R S I_{t}=R S_{t} /\left(1+R S_{t}\right) \\
& R S_{t}=\sum_{k=0}^{13} \max \left(P_{t-k}-P_{t-1-k}, 0\right) / \sum_{k=0}^{13} \max \left(P_{t-1-k}-P_{t-k}, 0\right)
\end{aligned}
$$

$R S I_{t}: t$ 기의 상대강도지수

$R S_{t}: t$ 기의 상대강도

$P_{t}: t$ 기의 종가

$$
\begin{aligned}
M F L_{t} & =M F_{t} /\left(1+M F_{t}\right) \\
M F_{t}= & \frac{\sum_{k=0}^{13} \max \left(P_{t-k}-P_{t-1-k}, 0\right) \times V o l_{t}}{\sum_{k=0}^{13} \max \left(P_{t-1-k}-P_{t-k}, 0\right) \times V o l_{t}}
\end{aligned}
$$

$M F I_{t}: t$ 기의 현금흐름지수

$M F_{t}: t$ 기의 현금흐름

$P_{t}: t$ 기의 종가

$\mathrm{Vol}_{t}: t$ 기의 거래량

$$
P S Y_{t}=\sum_{k=0}^{11}\left(\frac{\max \left(P_{t-k}-P_{t-1-k}, 0\right)}{P_{t-k}-P_{t-1-k}}\right) / 12
$$

$P S Y_{t}: t$ 기의 투자심리선

$P_{t}: t$ 기의 종가

$$
B S_{t}=\left(B V_{t}-S V_{t}\right) /\left(B V_{t}+S V_{t}\right)
$$

$B S_{t}: t$ 기의 개인투자자 순매수수량 비율

$B V_{t}: t$ 기의 개인투자자 매수수량

$S V_{t}: t$ 기의 개인투자자 매도수량

$$
\Delta I D_{t}=\left(I D_{t}-\frac{1}{24} \sum_{t=-24}^{-1} I D_{t}\right) / I D_{t}
$$

$\Delta I D_{t}: t$ 기의 투자자예탁금 증가율

$I D_{t}: t$ 기의 투자자예탁금 잔고 
한국증권학회지 제49권 6호 (2020)

$$
\text { Turn }_{t}=\frac{\text { Vol }_{t}}{\text { Share }_{t}} \times \frac{R_{t}}{\left|R_{t}\right|}-\frac{1}{60} \sum_{t=-60}^{-1}\left(\frac{\text { Vol }_{t}}{\text { Share }_{t}} \times \frac{R_{t}}{\left|R_{t}\right|}\right)
$$

Turn $_{t}: t$ 기의 상장주식거래회전율

$R_{t}: t$ 기의 수익률

$\mathrm{Vol}_{t}: t$ 기의 거래량

Share $_{t}: t$ 기의 상장주식수

$$
\Delta \operatorname{Margin}_{t}=\text { Margin }_{t} / \operatorname{Margin}_{t-1}-1
$$

$\Delta \operatorname{Margin}_{t}: t$ 기의 신용융자 증가율

Margin $_{t}: t$ 기의 신용융자 잔고

$$
\triangle C E I_{t}=C E I_{t} / C E I_{t-1}-1
$$

$\triangle C E I_{t}: t$ 기의 소비자기대지수 증가율

$C E I_{t}: t$ 기의 소비자기대지수

$$
\Delta \text { Fund }_{t}=\text { Fund }_{t} / \text { Fund }_{t-1}-1
$$

$\Delta$ Fund $_{t}: t$ 기의 주식형펀드순자산 증가율

Fund $_{t}: t$ 기의 주식형펀드순자산

$$
S E_{t}=\text { Stock }_{t} /\left(\text { Stock }_{t}+\text { Bond }_{t}\right)
$$

$S E_{t}: t$ 기의 주식발행비중

Stock $k_{t}: t$ 기의 주식발행금액

Bond $_{t}: t$ 기의 채권발행금액

\section{〈부록 2〉 차익거래 제약 변수 측정}

$$
\begin{aligned}
& V K O S P I=100 \times \sqrt{\left[T_{1} \sigma_{1}^{2} \times\left(\frac{N_{T_{2}}-N_{30}}{N_{T_{2}}-N_{T_{1}}}\right)+T_{2} \sigma_{2}^{2} \times\left(\frac{N_{30}-N_{T_{1}}}{N_{T_{2}}-N_{T_{1}}}\right)\right] \times \frac{N_{365}}{N_{30}}} \\
& \operatorname{VKOSPI}^{+}=100 \times \sqrt{\sigma_{1}^{2}}
\end{aligned}
$$

VKOSPI: 최근월물 잔존만기 30일 미만인 경우 변동성 지수 $V K O S P I^{+}$: 최근월물 잔존만기 30일 이상인 경우 변동성 지수 $N_{T_{1}}:$ 최근월물 잔존기간 
The Effects of Investor Sentiment and Limits-to-Arbitrage on the Idiosyncratic Volatility Puzzle

$N_{T_{2}}$ : 차근월물 잔존기간

$N_{365}$ : 연간 기간

$N_{30}: 30$ 일 기간

$T_{1}$ : 최근월물 잔존기간/연간 기간

$T_{2}$ : 차근월물 잔존기간/연간 기간

$\sigma_{1}^{2}$ : 최근월물 변동성

$\sigma_{2}^{2}$ : 차근월물 변동성

$$
\Delta T E D_{t}=\left(\text { KORIBOR }_{t}-K T_{t}\right) /\left(\text { KORIBOR }_{t-1}-K T_{t-1}\right)-1
$$

$\Delta T E D_{t}: t$ 기의 $\mathrm{TED}$ 스프레드 증가율

$K_{\text {ORIBOR }}: t$ 기의 1 년만기 KORIBOR수익률

$K T_{t}: t$ 기의 1 년만기 국채수익률

$$
\Delta C D S_{t}=\left(B B B_{t}-A A_{t}\right) /\left(B B B_{t-1}-A A_{t-1}\right)-1
$$

$\triangle C D S_{t}: t$ 기의 신용 스프레드 증가율 $A A_{t}: t$ 기의 3 년만기 $\mathrm{AA}$-회사채금리 $B B B_{t}: t$ 기의 3 년만기 $\mathrm{BBB}$-회사채금리

$$
\Delta B A S_{t}=\left(H_{\text {High }}-\operatorname{Low}_{t}\right) /\left(\text { High }_{t-1}-\text { Low }_{t-1}\right)-1
$$

$\Delta B A S_{t}: t$ 기의 호가 스프레드 증가율

$H \mathrm{H} h_{t}: t$ 기의 일중 최고가

Low $_{t}: t$ 기의 일중 최저가

$$
I L L I Q_{i, t}=\frac{1}{D_{i, t} \sum_{t=1}^{D_{i, t}}\left|R_{i, t}\right| / A M T_{i, t}}
$$

$I L L I Q_{i, t}: t$ 기의 $i$ 주식의 비유동성 지표

$R_{i, t}: t$ 기의 $i$ 주식의 수익률

$D_{i, t}: t$ 기의 $i$ 주식의 거래일

$A M T_{i, t}: t$ 기의 $i$ 주식의 거래대금

$$
\Delta \operatorname{Vol}_{i, t}=\operatorname{Vol}_{i, t} / \operatorname{Vol}_{i, t-1}-1
$$

$\Delta \operatorname{Vol}_{i, t}: t$ 기의 $i$ 주식의 주식거래량 증가율

$V_{o l}: t$ 기의 $i$ 주식의 거래량 
한국증권학회지 제49권 6호 (2020)

$$
\Delta \text { Cov }_{i, t}=\text { Coverage }_{i, t} / \text { Coverage }_{i, t-1}-1
$$

$\Delta \operatorname{Cov}_{i, t}: t$ 기의 $i$ 주식의 투자의견빈도 증가율

Coverage $_{i, t}: t$ 기의 $i$ 주식의 투자의견빈도

$$
\Delta H i t_{i, t}=H i t_{i, t} / H i t_{i, t-1}-1
$$

$\Delta H i t_{i, t}: t$ 기의 $i$ 주식의 가격제한 증가율

$H i t_{i, t}: t$ 기의 $i$ 주식의 가격제한폭 도달 횟수

$$
\Delta \text { Short }_{i, t}=\text { Short }_{i, t} / \text { Short }_{i, t-1}-1
$$

$\Delta$ Short $_{i, t}: t$ 기의 $i$ 주식의 공매도 거래 증가율

Short $_{i, t}: t$ 기의 $i$ 주식의 대차거래 체결

$$
\Delta \text { Bal }_{i, t}=\text { Balance }_{i, t} / \text { Balance }_{i, t-1}-1
$$

$\Delta \mathrm{Bal}_{i, t}: t$ 기의 $i$ 주식의 공매도 잔고 증가율

Balance $_{i, t}: t$ 기의 $i$ 주식의 대차거래 잔고 